\title{
Distributed Groundwater Recharge Potentials Assessment Based on GIS Model and Its Dynamics in the Crystalline Rocks of South India
}

Fauzia Fauzia ( $\sim$ fauzia9800@gmail.com )

CSIR-National Geophysical Research Institute, Hyderabad- 500007, India

Surinaidu Lagudu

National Geophysical Research Institute

Abdur Rahman

National Geophysical Research Institute

Shakeel Ahmed

National Geophysical Research Institute

\section{Research Article}

Keywords: Groundwater, crystalline rocks, South India, weighted overlay index, infiltration tests

Posted Date: January 15th, 2021

DOI: https://doi.org/10.21203/rs.3.rs-145760/v1

License: (c) (i) This work is licensed under a Creative Commons Attribution 4.0 International License.

Read Full License 
Distributed groundwater recharge potentials assessment based on GIS model and its dynamics in the crystalline rocks of South India

\author{
Fauzia Fauzia $^{\text {a,b }}$, L. Surinaidu ${ }^{\text {a }}$, Abdur Rahman ${ }^{\text {a,b }}$ and Shakeel Ahmed ${ }^{\text {a }}$ \\ ${ }^{a}$ CSIR-National Geophysical Research Institute, Hyderabad- 500007, India \\ ${ }^{\mathrm{b}}$ Academy of Scientific \& Innovative Research (AcSIR), Ghaziabad- 201002, India \\ Corresponding author: fauzia@ ngri.res.in
}

\title{
Abstract
}

Extensive change in land use, climate, and over-exploitation of groundwater has increased pressure on aquifers, especially in the case of crystalline rocks throughout the world. To support sustainability in groundwater management, require proper understating of groundwater dynamics and recharge potential. The present study utilized a GIS-based Weighted Overlay Index (WOI) model to identify the potential recharge zones and to gain deep knowledge of groundwater dynamics. The in situ infiltration tests have been carried out, which is the key process in groundwater recharge and is neglected in many cases for WOI. In the WOI, 10 thematic layers from the parameters influencing and involved in the recharge process are considered to identify potential recharge zones. The results suggested a significant underestimation of recharge potential, without considering site-specific infiltration rates that one needs to be considered. The WOI model considering in situ infiltration information classified the entire area into four recharge zones, good, moderate, poor, and very poor. The final integrated map compared with the real-time field data like water level fluctuation and infiltration to analyse occurrence and quantification of recharge. The estimated average groundwater draft is $21.9 \mathrm{mcm}$ while annual renewable recharge is only $5.7 \mathrm{mcm}$ that causing a continuous fall of the groundwater table. The study is useful in selecting regions with more focussed recharge studies and suggested that the need of reducing groundwater demand with the change in cropping pattern through a predictive decision support tool. 
28 Keywords: Groundwater, crystalline rocks, South India, weighted overlay index, infiltration

29 tests

\section{Introduction}

Groundwater resources have a significant role in marine and terrestrial ecosystems ${ }^{1,2}$. It is also use for a range of purposes including domestic, agricultural and industrial applications ${ }^{3-7}$. However, the recent trend of groundwater levels especially in semi-arid regions of crystalline aquifers is depleting at alarming levels due to over-exploitation of groundwater than the recharge for various applications particularly for agriculture ${ }^{8}$. Groundwater recharge is a part of the hydrologic cycle that has a significant share in the water balance at the local, regional or global scale ${ }^{9}$. It assumes that the semi-arid areas are critical parts of the complete water balance of the earth's sub-surface ${ }^{10}$. Surface water resource in semi-arid areas is limited; thus, to meet the water requirements for different uses, groundwater forms a reliable resource all over the world ${ }^{11-13}$. The recharge from precipitation to groundwater in semi-arid to arid conditions varies essentially in space, where the extreme climate of low and inconsistent precipitation and high annual temperature hampers the recharge ${ }^{14}$. The efforts made to infiltrate precipitation water as aquifer storage and its quantification based on geospatial information systems make recharge efforts poorly successful over the globe ${ }^{15,16}$. Reliable estimation of recharge and its forecast remain challenging to numerous researchers and an open-ended question, mostly lack understating on the origin and controls on infiltration and recharge mechanism particularly in the changing environment ${ }^{14}$. In semi-arid areas, groundwater recharge takes place through various ways that can be incorporated; (1) direct recharge underneath rivers streams and lakes, (2) focused recharge at the catchment margin, (3) aerially dispersed infiltration through the unsaturated zone ${ }^{15,17}$. Simply, recharge appears to increase in zones of low topography with shallow-rooted vegetation and suitable soils that drain well ${ }^{11,18,19}$. 
53 The recent advances in geospatial and digital image processing technologies have empowered researchers to better understand the areas in which natural recharge takes place using a combination of semi-static information, for example, topography, geology, soil types, vegetation, etc. ${ }^{14,20,21}$. Many researchers have applied geospatial techniques for the integration of different thematic layers including climate, hydrogeological and hydrological information to identify suitable recharge sites for example in south western Asia ${ }^{12,22-28}$, in Africa ${ }^{29,30}$ and in Arabian Peninsula ${ }^{31,32}$. All studies have used the same type of information and considered soil properties of very low resolution; however, location or site specific soil infiltration rates were neglected which will have a major bearing on the quantity of recharge in temporal and spatial scales.

Groundwater is a renewable natural resource; however, this vital life-sustaining resource recharge has been dramatically decreased over the last 4-5 decades due to different forms of anthropogenic activities and distorted innovations and technologies ${ }^{28}$. A better comprehension of groundwater recharge capacity is its vital importance for water resource allocation and management for sustainable development. In the present study, primary data of intensive infiltrations tests that carried out during the study period and basement depth were included to general climate, hydrogeological and hydrological layers to understand its role in recharge dynamics and to compare with existing integration methods for the identification of suitable recharge sites by taking Maheshwaram crystalline watershed located in South India.

\section{Description of the study area}

The Maheshwaram watershed is located $35 \mathrm{~km}$ south of Hyderabad in the state of Telangana that covers $53 \mathrm{~km}^{2}$ of the area. The area is characterized by moderate topography with an elevation range between 670 to 590 meters above sea level (AMSL) (Fig. 1) with a slope of about $>4$ percent (Fig. 3b). There are no perennial streams in the area and water flows in the streams during the rainy seasons only. The area encounters a semi-arid climate and is 
constrained by the regularity of the monsoon (monsoon period: June- October). The mean annual rainfall is approximately $750 \mathrm{~mm}$, over 90 percent of which occurs during the monsoon period. The average annual temperature is $26^{\circ} \mathrm{C}$; while the maximum daily temperature reaches $45^{\circ} \mathrm{C}$ in the summer (March-May). The geology is generally homogeneous and composed of granites of the Archean age. The study area is a representative catchment of Southern India regarding overexploitation of its hard rock reservoir (more than 700 bore wells being in use), rural social economy (mainly based on conventional agriculture), its cropping patterns (rice field dominating), and agricultural practices. The main agricultural patterns in the area are rice, vegetables, and flowers, with some orchards of mangoes, guavas, and grapes. The major source of water for irrigation in the area is groundwater.

Hydrological settings. Aquifers usually are formed in hard rock terrains by intense weathering for extended periods of time. Because of the occurrence of fractures, the aquifers are anisotropic and heterogeneous. Various mechanisms are invoked to describe the cause of the fractures, including cooling stress within the magma, subsequent tectonic movements ${ }^{33}$ or lithostatic mechanisms of decompression ${ }^{34}$. Nevertheless, some studies have shown that 94 fracturing is the product of the weathering cycle $^{35,}{ }^{36}$. The Maheshwaram watershed weathering profile is dominated by a multiphase weathering cycle caused by the Indian Peninsula's geodynamic history ${ }^{37}$. The weathering strata from the top downwards as follows:

97 - Red Soil (a thin 10-40 cm layer)

98 - Sandy regolith layer (1-3 m thick), locally covered by a lateritic layer (thickness $<50$ $\mathrm{cm})$

- Laminated Saprolitic layer (10-15 m thick). The layer is distinguished by penetrating horizontal millimeter-spaced laminated structures and an irregular pattern of mostly subhorizontal, as well as some partially filled nearly vertical fissures with clayey minerals 
retained. Both laminated saprolite layers and sandy regoliths have some granite corestones (preserved fresh rock).

- $\quad$ Fissured granitic layer $(15-20 \mathrm{~m})$ - In fissured fresh granite, some clayey minerals and the weathered granite generally filled the fissures partially.

$107 \quad$ B Bedrock - the unfissured granite.

108 Throughout the fissured granite and the laminated saprolite layer collectively forms the aquifer. Therefore, a two-tier structure, that is, weathered and fissured aquifers, coexists almost throughout the region. In general, when water-saturated, the laminated saprolite horizon is weakly transmissive with large volume, whereas the fissured layer is weakly capacitive, but strongly transmissive ${ }^{38}$. Besides, the lateral permeability in the study area is typically greater than that of the vertical one ${ }^{39}$.

In the study region the general groundwater flow direction is mainly regulated by topography, that is, from south to north. The water level was shallow before the inception of borewell irrigation in the 1970s and lay in semi-confined conditions in the saprolite region. Because groundwater has been over-exploited since the accessibility of borewells, the water level has decreased and the groundwater occurrence is now under unconfined conditions predominantly in the fissured horizon ${ }^{40}$. Borewell yields are moderate (negligible to 20 $\mathrm{m}^{3} / \mathrm{hr}$ ) except those tap deep fissures in areas of tectonic origin, whereby yields are extremely high $^{39}$. The groundwater water table depths range from 15 to $25 \mathrm{~m}$ in the study area and are 122 isolated from surface water. The main problem of the study area is unmanaged recharge and over-exploitation causes continuous depletion of water levels from the last decades. Our main objective of this study is to find out potential recharge zones that trigger managed aquifer recharge for the security of groundwater in the future. 


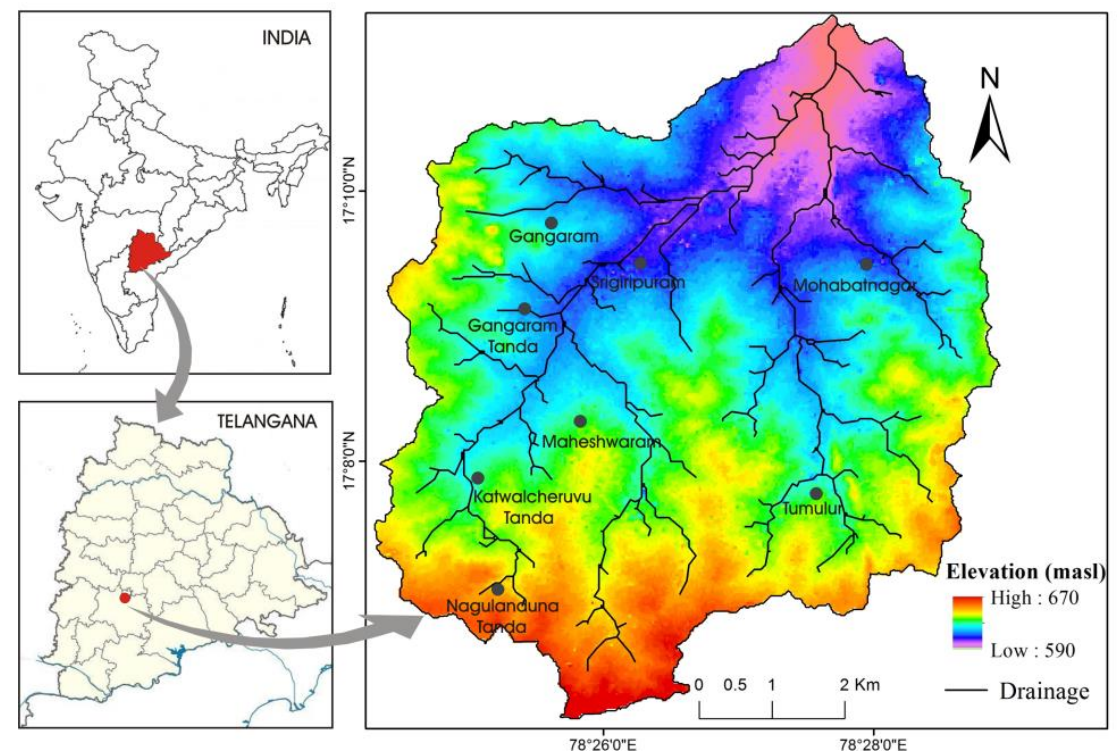

Figure. 1. Location map of the study area showing elevation with the drainage system

\section{Materials and methods}

\section{Data collection and processing}

130 Infiltration. Double ring infiltrometer (Measurements as per ASTM D3385-03 standard test strategy $)^{41}$ is used for soil infiltration tests in the study area. In the current study, 15 infiltration tests were carried out in February 2019 that spreads across the study area to find out the infiltration rates under different soil conditions. The diameters of the inner and outer rings of the double ring infiltrometer are 30 and $60 \mathrm{~cm}$ respectively. They were set on the ground surface and safely fixed $10 \mathrm{~cm}$ into the ground. The outer ring helps to avoid any leakage in the lateral direction from the sides of the ring. From the inner ring, infiltration was recorded with the help of a stopwatch at 1minute interval for the first 6 minutes; every 2 minutes from 6 to 12 minute; every 5 minutes from 15 to 50 minutes, every 10 minutes from 50 to 80 minutes, then every 20 minutes from 80 to 180 minutes and every 30 minutes from 180 to 240 . The tests were carried out until there is no further infiltration of water. The estimation of infiltration rates was carried out by using equation (1):

$$
\begin{aligned}
& \text { Infiltration Rate }(\mathrm{Ir})=\frac{a}{b} \times 60 \mathrm{~mm} / \mathrm{hr} \\
& \text { Area of the ring }(A)=3.142 \times(15)^{2} \mathrm{~cm}^{2}
\end{aligned}
$$


Where $a$ is infiltration rate in $\mathrm{mm}$, that estimated as the volume of the water added to the inner ring; $b$ is the time interval (in minutes) between two successive readings.

Groundwater levels. The groundwater levels have been manually monitored two times a year (pre and post-monsoon season) using Water Level Indicator (WLI) from the year 2008 to 2019 through a network of observation wells, distributed across the area. The data have also been crossed checked with a few AWLR installed in the area within the network.

\section{Thematic layers}

All thematic layers were extracted from secondary sources and only the maps which were not published are only presented here.

Soils. Geology, physiography and climate describe soils and has a significant role in runoff and groundwater recharge. Three kinds of soils are found in the investigation region, viz. Alfisols, entisols, inceptisols (Fig 2a). For the study area soil, the mean particle-size fractions indicate the percent of clay, silt and sand in Alfisol are 19, 12 and 69\%, and in Entisol 22, 21, and $56 \%$, respectively ${ }^{42}$.

Geology. The geology of the area mostly covers Archean granites. Biotite granite, quartz vein, dolerite dyke and leucocratic granite are the essential lithological units of the area (Fig. 2b). Quartz vein and dolerite dyke act as a barrier for the movement of groundwater.

Geomorphology. The area is dominated by different depositional and erosional geomorphic characters, like pediments, pediplains, outcrops of rocks and valley fills (Fig. 2c). Area covered by shallow weathered pediplains is depicted about the flat landscape with a gentle gradient. A fairly thick weathered material is a prevailing geomorphological part of the study area. Moderately weathered pediplains were found in different places in the area. Valley fills are commonly unconsolidated alluvial materials comprising of silt, sand, pebbles, and gravels accumulated along the base of the drainage valley. 
Drainage density. The drainage was derived from $30 \mathrm{~m}$ resolution DEM using spatial

172

173

analyst tools in ArcGIS. The key steps include sink filling, flow path recognition, flow accumulation calculation and definition of the stream $^{43}$. The threshold value of 50 was selected for the drainage network extraction. Drainage density is characterized as the ratio of entire stream segment lengths in a basin to the area of the basin $\left(\mathrm{Km} / \mathrm{Km}^{2}\right)$. The range of drainage density varied between $0-11 \mathrm{~km} / \mathrm{km}^{2}$. The drainage density of the investigation zone was set up by using a line density tool in ArcGIS software (Fig. 2d).
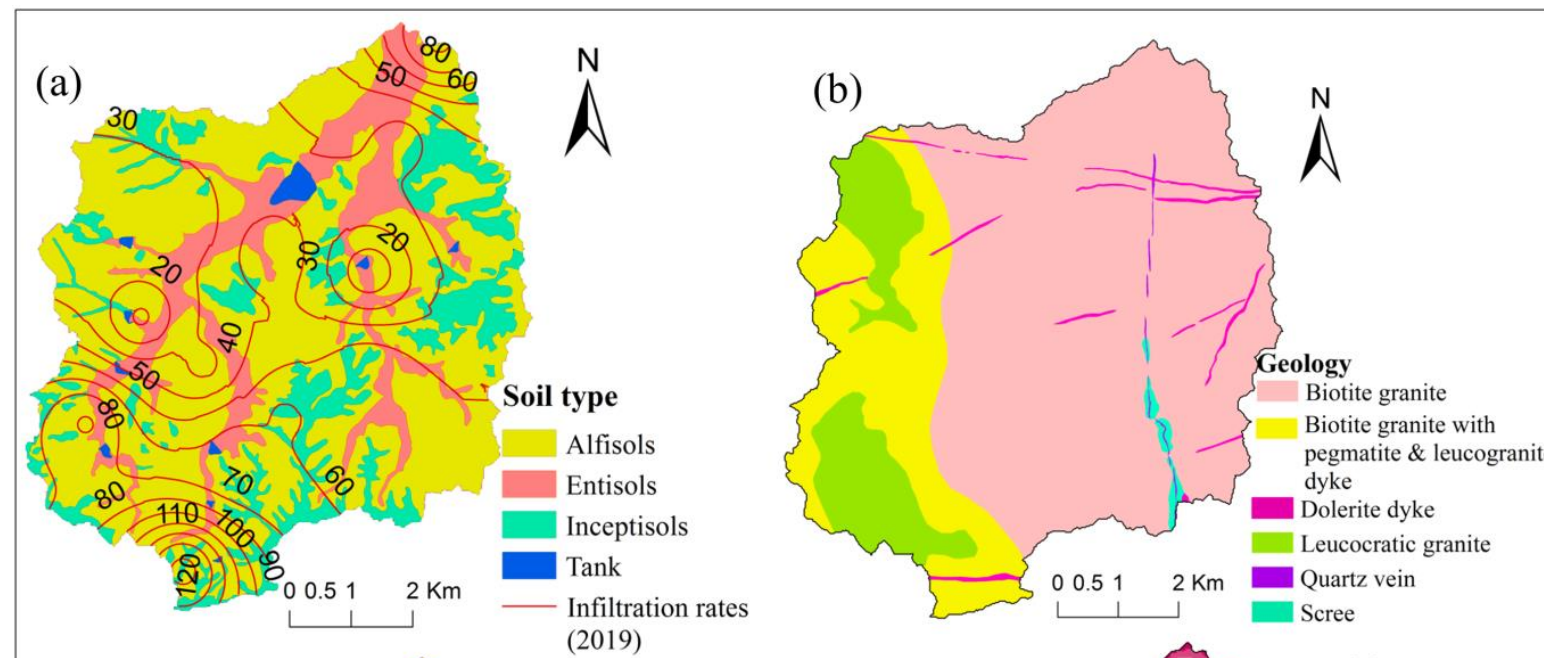

(c)
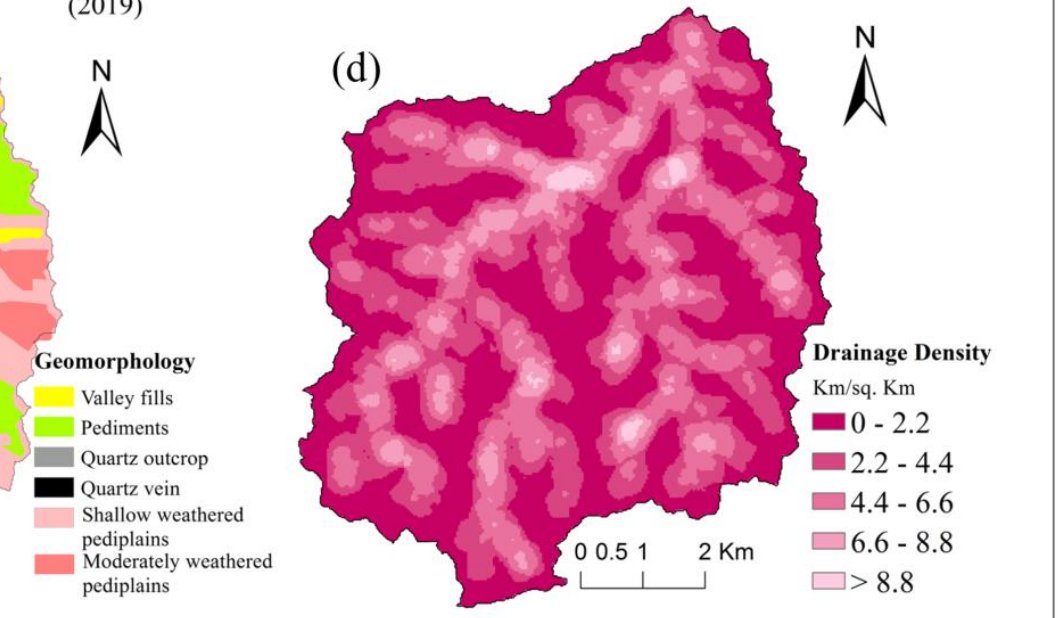

Figure. 2. Map showing input thematic layers (a) soil with infiltration rates $(\mathrm{mm} / \mathrm{hr})$, (b) geology, (c) geomorphology, and (d) drainage density of Maheshwaram watershed, India.

\subsubsection{Slope}


The watershed is dominantly a flat land. The slope varies from 0 to more than 4 percent (Fig. 3a). Compared to the low-slope zone, a high slope will cause less infiltration and greater runoff.

Land use and land cover. Land use and land cover (LULC) has an indispensable role in prospecting for groundwater. Various LULC influence recharge rates, surface flow, and evapotranspiration. LULC map has been prepared from LANDSAT 8 imagery with the help of unsupervised classification using ArcGIS and limited field visits. The derived land use maps in the Maheshwaram exhibits a range of categories include forest, orchard, paddy, villages, vegetables, barren land, tanks and other crops (Fig. 3b).

Fissure. A high - density horizontal fissure in the first few meters and the density of subhorizontal and subvertical fissures declining with depth are typically described by the fissured layer ${ }^{33,37,38,40}$. The fissured layer is believed to be the capacitive feature of the complex aquifer ${ }^{35}$. In the Maheshwaram watershed, fissured granite occupies 15- 20 meters, below the ground surface ( $\mathrm{m}, \mathrm{bgs})$, the fissures are partly filled with a few clay minerals and weathered granite. Using flow meter measurements of 19 wells, the hydraulic conductivity and fracture density of conductive fissure zones were studied ${ }^{37}$, which established the depth position of hydraulically conductive fractures. The Sum of all the fissures present in each well was taken separately to prepare the contour map for the recharge studies (Fig. 3c). Marechal et al. (2004) provided a complete explanation of the measurements and data interpretation method.

Lineament. Lineaments are characterized as naturally occurring linear or curvilinear surficial features $^{44}$ that express subsurface geology and structural features like fault, fractures or joints ${ }^{14}$. Lineaments in the hard rock terrains represent regions and zones of fracturing and faulting that result in expanded secondary porosity and permeability and are acceptable pointers of groundwater ${ }^{45}$. Lineament map was taken from 44 and a density map was 
207 prepared using a line density tool in ArcGIS 10.3 (Fig. 3d). Lineament density is the total 208 length of all the lineaments present in the unit area within the watershed. In the present study, 209 the estimated density ranges from $0-3.5 \mathrm{~km} / \mathrm{km}^{2}$.

210 Depth to basement. The depth of the basement is nothing but unfissured granitic bedrock 211 which was derived by geophysical investigations and borewell lithologs for the study area ${ }^{40}$.

212 Contour map for the fresh basement has been prepared using ArcGIS software (Fig. 3e) and 213 the depth ranges from 25 to 69 meters, below ground surface (m, bgs). 


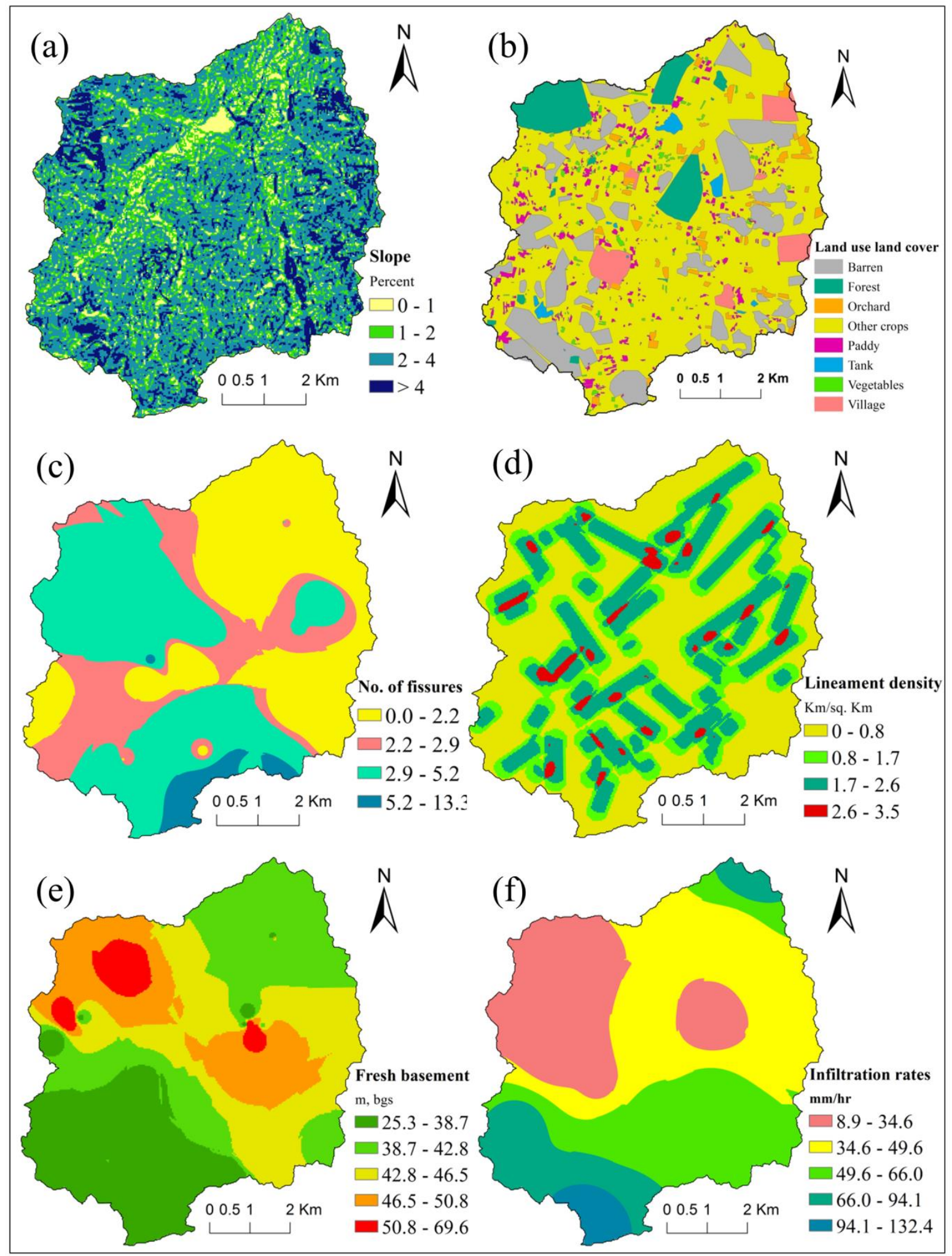

215 Figure. 3. Map showing input thematic layers (a) slope (b) Lulc (c) fissures (d) lineament

216 density, (e) depth to basement, and (f) infiltration rates of Maheshwaram watershed, India. 


\section{Weighted Overlay Index}

219 Weighted Overlay Analysis (WOA) is a method to produce integrated analysis by applying a 220 similar range of values to input components ${ }^{46}$. The major processes in methodology include 221 reclassification of each layer and classification of groundwater potential recharge zones by 222 the integration of reclassified layers by applying Weighted Overlay Index method. Thematic maps mentioned above were reclassified and georeferenced to a standard point of reference in the Universal Transverse Mercator (UTM) plane coordinate system, followed by the weights assigned as per their possible impact on groundwater recharge using the Weighted Overlay Index method ${ }^{47,48}$. The weights are given to respective layers to give relative significance to recharge $\mathrm{e}^{14,25,28}$. Each thematic layer reclassified to low, moderate, and high from the lowest to the highest recharge potential dependent on natural gaps in the data.

Figure 4 shows the methodology adopted in the current study for the integration of different layers followed by overlay analysis, cross validation and recharge quantification. Weights based on priority for groundwater recharge are presented in Table 1. Depending on the knowledge-based hierarchy, the different classes of each theme were allocated from 1 to 9 ranking. The overall weights of the final integrated map were obtained as product or sum of weights allocated to different layers as per their suitability. The final map was categorized into four distinct groundwater recharge zones that are good, moderate, poor, and very poor. preparation of recharge map. 


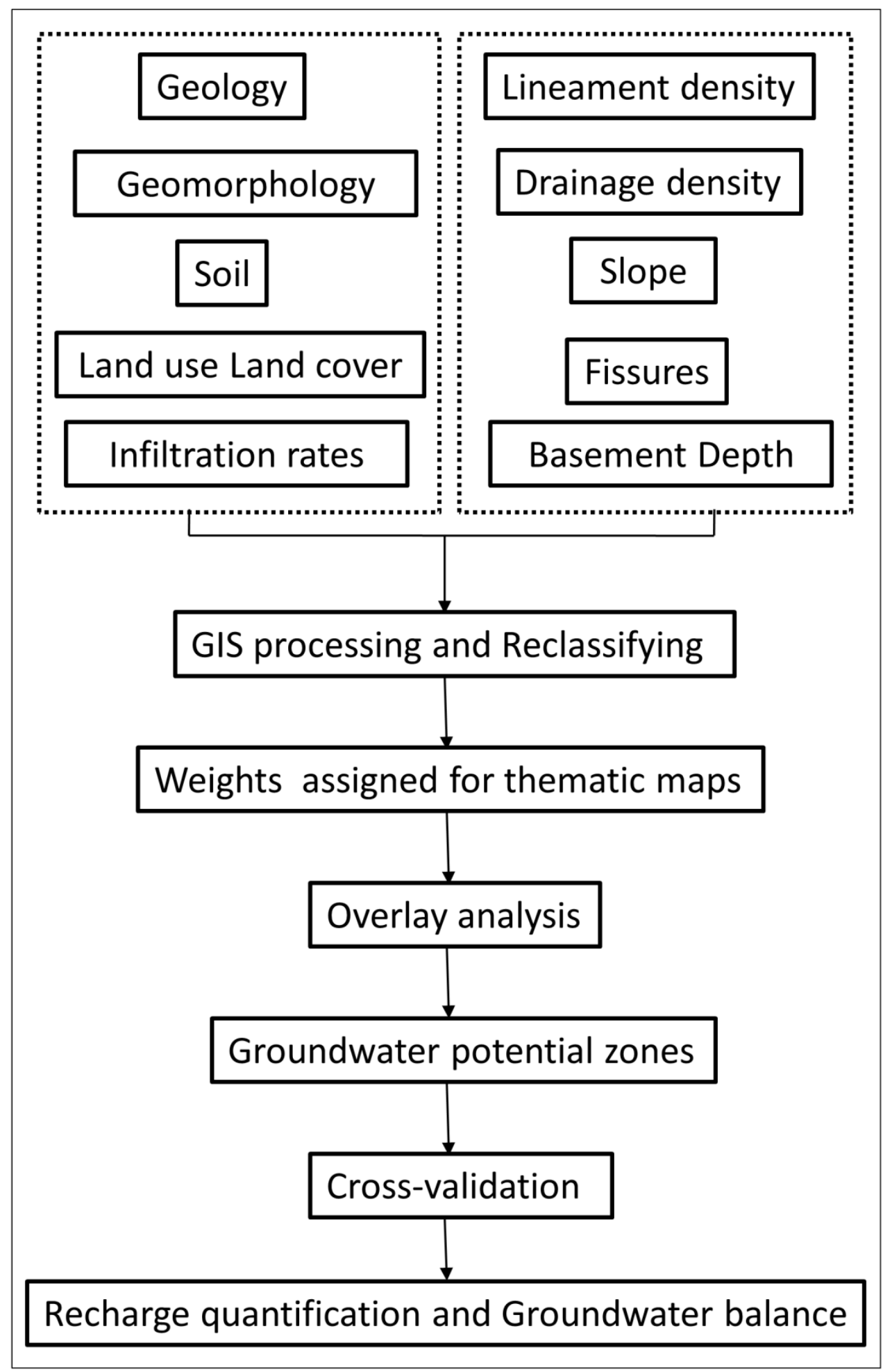

Figure. 4. Flow chart showing WOI methodology adopted in the study area for the evaluation of potential groundwater recharge zones. 


\begin{tabular}{|c|c|c|c|c|c|c|}
\hline Layers & Data sources & $\begin{array}{c}\text { Weights } \\
\text { (without } \\
\text { infiltration) } \\
\text { (Fig. 5a) }\end{array}$ & $\begin{array}{l}\text { Weights } \\
\text { (with } \\
\text { infiltration) } \\
\text { (Fig. 5b) }\end{array}$ & $\begin{array}{l}\text { No. Of } \\
\text { classes }\end{array}$ & $\begin{array}{c}\text { Class } \\
\text { description }\end{array}$ & Ranks \\
\hline \multirow{8}{*}{ LULC } & \multirow{8}{*}{$\begin{array}{l}\text { Knowledge-based } \\
\text { supervised } \\
\text { classification } \\
\text { technique and } \\
\text { maximum likelihood } \\
\text { classifier (generated } \\
\text { in the present study) }\end{array}$} & \multirow{8}{*}{12} & \multirow{8}{*}{9} & \multirow{8}{*}{8} & Barren & 1 \\
\hline & & & & & Village & 2 \\
\hline & & & & & Vegetables & 6 \\
\hline & & & & & Other crops & 5 \\
\hline & & & & & Paddy & 7 \\
\hline & & & & & Orchard & 7 \\
\hline & & & & & Forest & 8 \\
\hline & & & & & Tanks & 9 \\
\hline \multirow{6}{*}{ Geology } & \multirow{6}{*}{ Dewandel et al., 2006} & \multirow{6}{*}{7} & \multirow{6}{*}{6} & \multirow{6}{*}{6} & Biotite granite & 4 \\
\hline & & & & & $\begin{array}{l}\text { Biotite granite } \\
\text { with pegmatite } \\
\text { and dyke }\end{array}$ & 5 \\
\hline & & & & & Scree & 4 \\
\hline & & & & & Leucogranite & 2 \\
\hline & & & & & Quartz vein & 6 \\
\hline & & & & & Dolerite dyke & 7 \\
\hline \multirow{6}{*}{ Geomorphology } & \multirow{6}{*}{$\begin{array}{c}\text { Modified from } \\
\text { Rashid et al., } 2012\end{array}$} & \multirow{6}{*}{8} & \multirow{6}{*}{7} & \multirow{6}{*}{6} & $\begin{array}{c}\text { Shallow } \\
\text { weathered } \\
\text { pediplains }\end{array}$ & 4 \\
\hline & & & & & $\begin{array}{l}\text { Moderately } \\
\text { weathered } \\
\text { pediplain }\end{array}$ & 5 \\
\hline & & & & & Quartz outcrop & 1 \\
\hline & & & & & Quartz vein & 6 \\
\hline & & & & & Pediments & 3 \\
\hline & & & & & Valley fills & 9 \\
\hline \multirow{4}{*}{ Soil } & \multirow{4}{*}{$\begin{array}{l}\text { Modified from } \\
\text { Condappa, } 2005\end{array}$} & \multirow{4}{*}{20} & \multirow{4}{*}{12} & \multirow{4}{*}{4} & Inceptisols & 5 \\
\hline & & & & & Alfisols & 8 \\
\hline & & & & & Entisols & 7 \\
\hline & & & & & Tanks & 9 \\
\hline \multirow{4}{*}{$\begin{array}{c}\text { Lineament } \\
\text { density }(\mathrm{Km} / \mathrm{sq} \\
\mathrm{Km})\end{array}$} & \multirow{4}{*}{$\begin{array}{l}\text { Modified from } \\
\text { Rashid et al., } 2012\end{array}$} & \multirow{4}{*}{20} & \multirow{4}{*}{14} & \multirow{4}{*}{4} & $0-0.8$ & 4 \\
\hline & & & & & $0.8-1.7$ & 6 \\
\hline & & & & & $1.7-2.6$ & 8 \\
\hline & & & & & $2.6-3.5$ & 9 \\
\hline \multirow{5}{*}{$\begin{array}{c}\text { Drainage } \\
\text { density }(\mathrm{Km} / \mathrm{sq} . \\
\mathrm{Km})\end{array}$} & \multirow{5}{*}{$\begin{array}{l}\text { SRTM DEM ( } 30 \mathrm{~m} \\
\text { resolution) }\end{array}$} & \multirow{5}{*}{8} & 0 & 5 & $0-2.2$ & 8 \\
\hline & & & 0 & 5 & $2.2-4.4$ & 7 \\
\hline & & & & & $4.4-6.6$ & 6 \\
\hline & & & & & $6.6-8.8$ & 5 \\
\hline & & & & & $>8.8$ & 4 \\
\hline Slope (in & SRTM DEM (30 m & 15 & 14 & 4 & $0-1.0$ & 8 \\
\hline percent rise) & resolution) & & & & $1.0-2.0$ & 6 \\
\hline
\end{tabular}




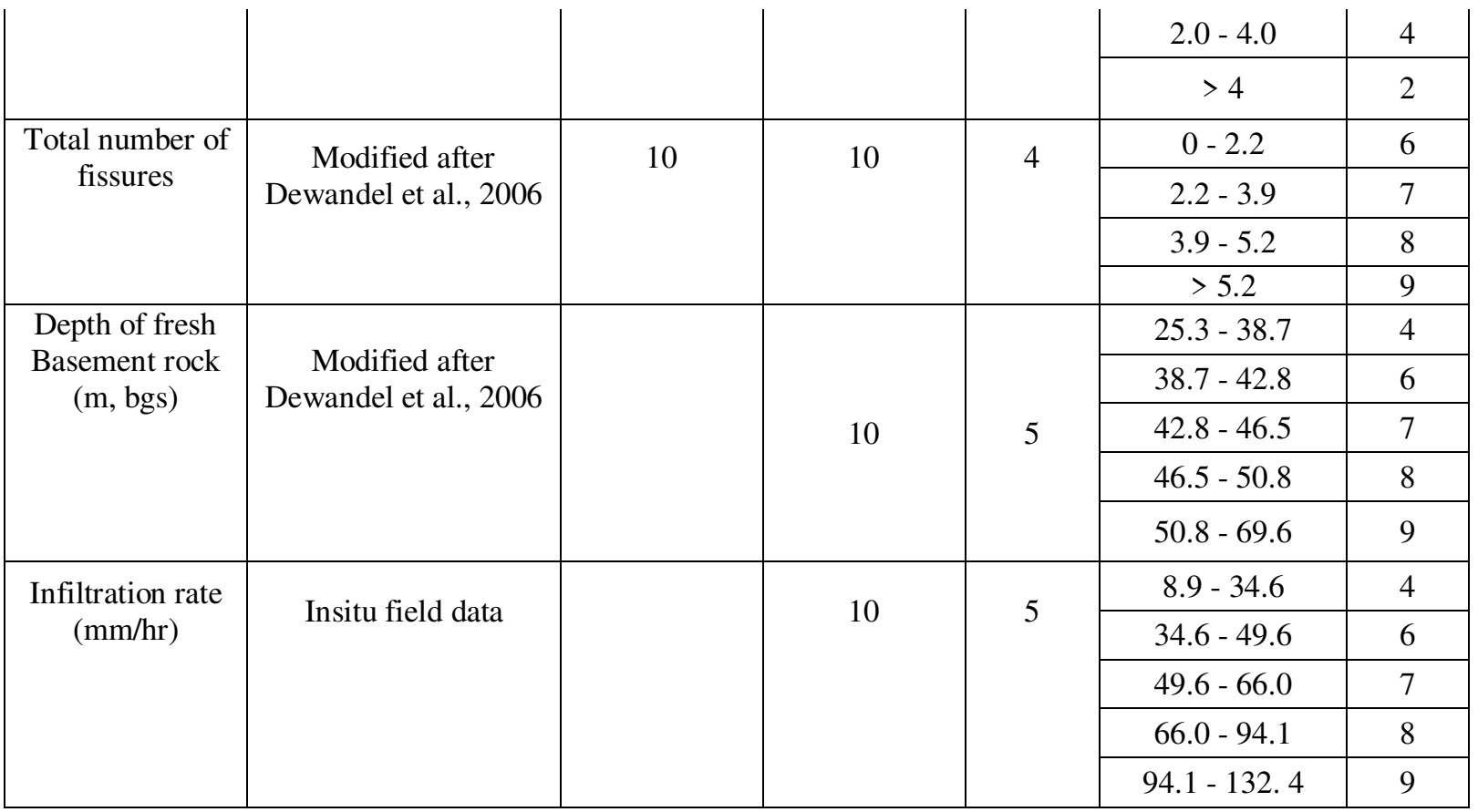

Table 1. Thematic layers used in weighted overlay analysis, their weights and class ranks assigned for the preparation potential recharge zones

\section{Estimation of groundwater recharge and draft}

The recharge is measured by using the water table fluctuation method using the following formula:

$$
\text { Recharge }=\text { Geographical area } \times \text { Water table fluctuation } \times \text { Specific yield }
$$

Specific yield (Sy) values were considered from the study is taken from the Ground Water Estimation Committee's recommended values ${ }^{51}$.

The average value of water level fluctuation from pre to post-monsoon in each recharge zone that has been classified by WOI has been taken to estimate recharge from the year 2008 to 2019.

The percentage of precipitation converted into groundwater recharge is shown in table 3. Owing to scanty rainfall and less surface water supplies, the study area relies mainly on groundwater for its irrigation. More than 70 percent of available groundwater resources are used by most of the administrative units (mandals). 
In the current study, the draft of groundwater has been estimated on the basis of the irrigated area statistics method for the period of 2008 to 2019, and the deficit amount of water has also been calculated by deducing the total groundwater draft to total recharge (Table 3). In this method, the groundwater draft has been calculated by multiplying various irrigated crops area (cultivated using groundwater) with the crop water requirement for each crop.

The total groundwater drafts for irrigation have been estimated by the following formula:

$$
\text { Total draft }=\text { Irrigated area } \times \text { Crop water requirement }
$$

For paddy, the crop water requirement taken is $0.95 \mathrm{~m}$ for monsoon, and horticulture and irrigated dry it is $0.6 \mathrm{~m}$ and $0.45 \mathrm{~m}$ for non-monsoon, respectively (after removing 50 percent of rainfall, i.e., $0.25 \mathrm{~m})^{52}$.

\section{Results and discussion}

Infiltration. Infiltration is one of the most important approach in the study of water movement in vadose zone. It is the most important and primary process in groundwater recharge. The basic way of evaluating groundwater resources is by use of Infiltration rates ${ }^{53}$. The infiltration rates vary widely across the area, such a wide variation could be explained by the nature of the soil, vegetation, geology, slope, etc. Infiltration rates are highest in the southernmost and northernmost part of the region whereas it is lowest in the south western part (refer Fig. 3f). Less infiltration rate at some places is primarily due to more clayey and silt in soils. Entisols are showing lower infiltration rates, which is possible because their soil profile contains more silt as compared to alfisols. Whereas alfisol soil has shown comparatively higher infiltration rates than entisol and inceptisol. The soil map with the contours of infiltration rates is shown in Figure 2a. Siltation is one of the most important reasons for low recharge as it acts as a barrier and does not allow the water to infiltrate beneath. When it comes to geology, it is obvious that hard and more resistant rocks do not allow the water to infiltrate, moreover, weathered and less resistant rocks will promote more recharge in the region. Vegetation is another reason that promotes infiltration. The higher the vegetation more will be the infiltration and lower vegetation will often lead to barren land. The infiltration rates are highest in cropland areas. 

layers (Geology, soil, geomorphology, lineament density, LULC, drainage density, fissures, and slope) were reclassified, followed by the weight assigned as per their relative impact on groundwater recharge (Table 1). Geology and geomorphology of a region are very significant characteristics in assessing an area's groundwater recharge zones ${ }^{53}$. High weights are assigned for quartz vein and dolerite dyke that act as a barrier for the movement of groundwater. Dolerite dyke are distributed in different parts of the area and oriented in E-W and SE-NW directions. Whereas, quartz vein following the N-S trend in the south-western part (Fig. 2b). A large part of the area is geologically occupied by biotite granite and biotite granite with pegmatite dyke, assigned higher ranks as they are more deeply weathered than leucocratic granite. Similarly, the high weight assigned for valley fills as they are mostly unconsolidated sediments that promote high recharge in the area. Valley fills are found in the middle parts following the drainage network of the study area (Fig. 2c). The region is primarily secured by coarse material with great vegetation spread. While the area covered by shallow and moderately weathered pediplains assigned as moderate, pediments are assigned as low to moderate as pediments comprise the lower weathered zone. A smooth and level buried pediment surface with smooth and flat surface comprises of shallow overburden of weathered material and is found mainly at the south western part while in the northern part of the region there are a few scattered patches. The low weight assigned for quartz outcrop, found in the western and south western part of the investigation area. Quartz is very resistant to weathering and does not support recharge. Negligible vegetation is found around rocky area. The water-holding capacity of a region relies on the types of soil as well as their permeability. The first step of transmission and infiltration of surface water to subsurface water is a function of texture and soil type ${ }^{55}$. A higher rank assigned to alfisol because it has less silt than entisol's soil that offers more percolation, and hence recharging (Fig. 2a). 
Drainage density and slope are the crucial parameters that control runoff and the infiltration of the area. Drainage density is a reverse function of permeability. The lesser the permeability a rock means, the lesser the infiltration of precipitation, which will then flow as surface runoff. It offers a well-developed and well drainage system. Higher drainage density shows low infiltration and consequently acts as poor groundwater recharge zones contrasted with low drainage density suggesting a reverse connection between the two. However, the slope is an important characteristic of terrain that expresses the steepness of the ground surface. The slope is compatible with the shallow groundwater hydraulic gradient and controls water runoff speed and infiltration rate ${ }^{56}$. Larger slopes yield less recharge because, during rainfall, the water obtained from the rainfall moves immediately down the steep slope. Thus, the saturated zone does not have enough residence time to infiltrate and recharge ${ }^{28}$. The drainage density and slope map of the Maheshwaram basin are shown in Figures $2 \mathrm{~d}$ and 3a, respectively. Drainage density of the area was reclassified and categorized as very low $(0-$ 2.2), low (2.2 - 4.4), high $(4.4-6.6) ;(6.6-8.8)$, very high $(>8.8)$. The high drainage density assigned lower weights, whereas low drainage density assigned higher ranks. The presence of strongly resistant and permeable rock is indicated by the poor drainage course network, while a higher drainage course shows extremely weak and impermeable rocks ${ }^{57}$. Slope values are reclassified and graded into five groups for flat and gentle slopes, such as flat (0 - 1), gentle $(1-2)$, steep (2 - 4), and very steep (> 4). High weights are given for flat and gentle slopes, whereas lower weights for steeper slopes. Groundwater recharge is high close to lineament zones as lineaments have a significant role in the recharge of groundwater in hard rock $\operatorname{areas}^{58}$. Lineament density (Fig. 3d) are reclassified and identified as low $(0-0.8)$, moderate $(0.8-1.7)$, high $(1.7-2.6)$, very high $(2.6-3.5)$. High lineament density assigned higher weights, as it allows water to percolate and is a good indicator of recharge zones. While the lower weights assigned to lower density accordingly. Fractures and faults play a very 
important role in groundwater replenishment as the zones of fracturing and faulting result in expanded secondary porosity and permeability and are acceptable pointers of groundwater recharge $\mathrm{e}^{45}$. According to the available data, the sum of the fissures presents in each well is taken for the recharge studies. The fissure map for the Maheshwaram basin is shown in Fig. 3c. For the present study, fissures are reclassified and categorized as low $(0-2.2)$, moderate (2.2 - 2.9), high (2.9 - 5.2), and very high (> 5.5). More number of fissures is assigned more weights, and fewer fissures are assigned higher weights. Similarly, Infiltration rates and fresh basement depth (Fig. 3e and 2f) are reclassified and categorized into five classes. Infiltration rates as very low $(8.9-34.6)$, low $(34.6-49.6)$ moderate $(49.6-66.0)$, high $(66.0-94.1)$, very high $(94.1-132.4)$ whereas very shallow $(25.3-38.7)$, shallow $(38.7-42.8)$, moderate (42.8 - 46.5), deep (46.5 - 50.8), very deep (50.8 - 69.6) for basement depth. Infiltration is a primary process in groundwater recharge. The Method of Infiltration suggests that a part of precipitation reaches the water table ${ }^{53}$. Infiltration rate is directly proportional to vegetation density, for example, the runoff will be less and infiltration will be more if the area is covered by heavy forest. The runoff yield is expanded from the area steadily from forest spread, grassland, agricultural land, barren land and urbanized developed land ${ }^{55}$. Water bodies are an important source of direct and continuous recharge. Water bodies and forests are allocated the most elevated position for groundwater recharge. The paddy fields, orchids and crop plantation with great vegetation spread advances the rate of infiltration and prevents excess runoff and in this way are allocated high weights for groundwater recharge. Rocky areas, barren lands and villages are given low weightage since the water penetration rate is poor. The distinguished groups of land use are mainly paddy, orchids; different crops like maize, vegetables, cotton, sunflower; forest, rocky outcrops, barren land and tanks (Fig. 3b).

Potential groundwater recharge areas. In the present study area, groundwater occurs in an unconfined aquifer ${ }^{40}$. In the present study, two different types of groundwater recharge 
potential maps were prepared. In the study we have provided static potential recharge maps in two different scenarios. The first one is routine hydrogeological parameters listed in Table 1 that most of the WOA analysis methods use. The second one is considering site-specific detailed soil infiltration rates and basement depths. The resulting maps have been classified as good, moderate, poor, and very poor groundwater recharge zones (Fig. 5). The area of potential recharge zone has been calculated as $2.2,41.4,51.2$ and $5.2 \%$ for the very poor, poor, moderate and good respectively first case (Fig. 5a) and in the second case, it is 0.1 , 34.1, 62.4 and $3.4 \%$ for very poor, poor, moderate and good respectively (Fig. 5b). The comparison of groundwater potential maps in the two cases indicated that underestimation of about $11 \%$ of potential groundwater recharge areas in the absence of site-specific soil infiltration rates and basement depths. The potential recharge zone scenario in Fig. $5 b$ has changed when infiltration rates and basement depth were considered. Poor and very poor recharge zones decrease while the moderate recharge zones impressively increased as compared to Fig. 5a. Fig. 5b indicates the potential recharge zones are highly influenced by basement depth and infiltration rate of the area.

As seen from Figure 5, good groundwater recharge zones often occur in the middle of the regions while a few patches are found in the eastern, north-western and southern part. High groundwater recharge areas are typically limited to the valley and low drainage density areas that have good infiltration potential. The moderate recharge zones are usually distributed all over the area, mainly in the shallow weathered pediplains of biotite granite and biotite granite with pegmatite and dyke and low lineament density. The poor and very poor recharge zones occur primarily in highlands to lowlands, but very poor recharge zones are relatively less in the middle parts. The poor and very poor recharge zones found in the rocky outcrop, high drainage density, steep slope, less lineament density and less no. of fissures and barren land 387 regions. 


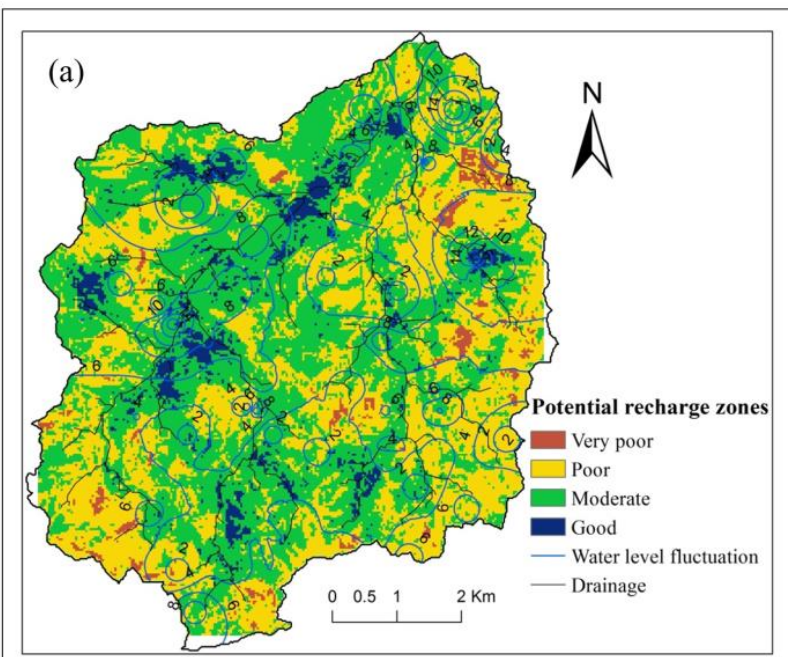

Area in percentage

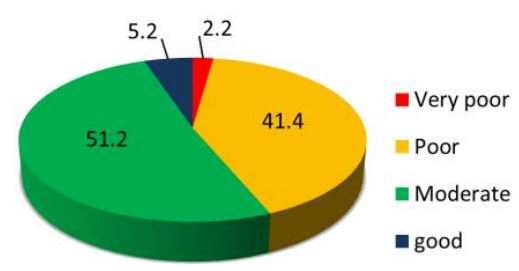

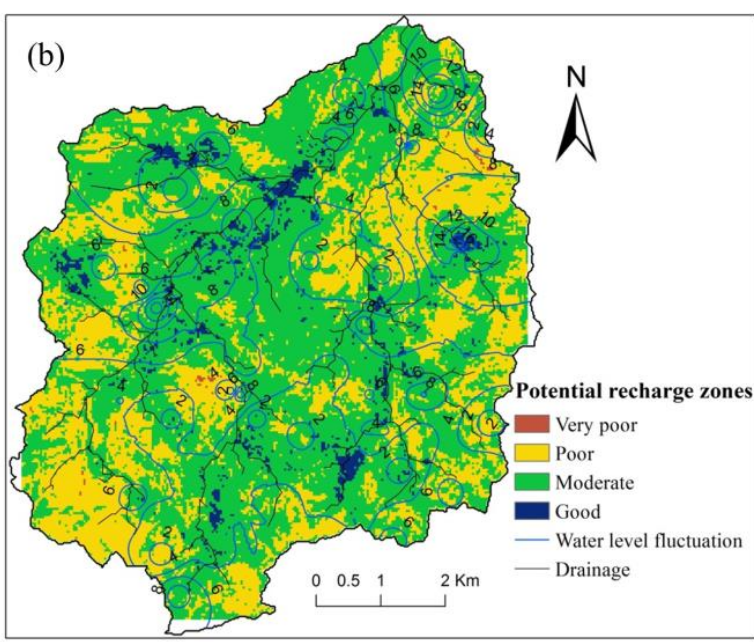

Area in percentage

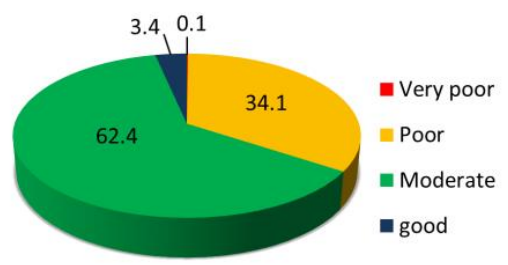

Figure. 5. Potential groundwater recharge zones (a) without infiltration rates and basement depth (b) with infiltration rates and basement depth.

\section{Correlation of potential groundwater recharge zones with water level fluctuation and}

rainfall. To check the validity of recharge potential maps generated from the WOA method, groundwater recharge zones delineated in this analysis are further crossed-checked with water level fluctuations from the year 2008 to 2019. The careful observations revealed that water level fluctuation is higher in the Northernmost (12 to $16 \mathrm{~m}, \mathrm{bgl})$, eastern and western parts $(10 \mathrm{~m}, \mathrm{bgl})$ of the region where WOA demarcated the zone as good to moderately recharge area (Fig. 5a and 5b). Whereas, poor recharge zones are showing less water level fluctuation can be seen in Fig. 5a and 5b. Average of pre and post-monsoon water levels from all the wells falling in low recharge zones and high recharge zones have been prepared to show how recharge (post-monsoon water level rise) is taking place in the two zones (Fig. 6a and $6 \mathrm{~b}$ ). The wells located in potentially very low and weak groundwater areas are observed to show fewer fluctuations in water level from pre to post-monsoon, which eventually results 
in low recharge. On the other hand, high groundwater recharge zones showing more pre and

404

405

406

407

408

409

410

411

412

413

post-monsoon water level fluctuation that results in more recharge. It is also noted that the trend of groundwater table depths is increasing (Fig. 6), indicates a marked decline in groundwater level with the response to the rainfall.

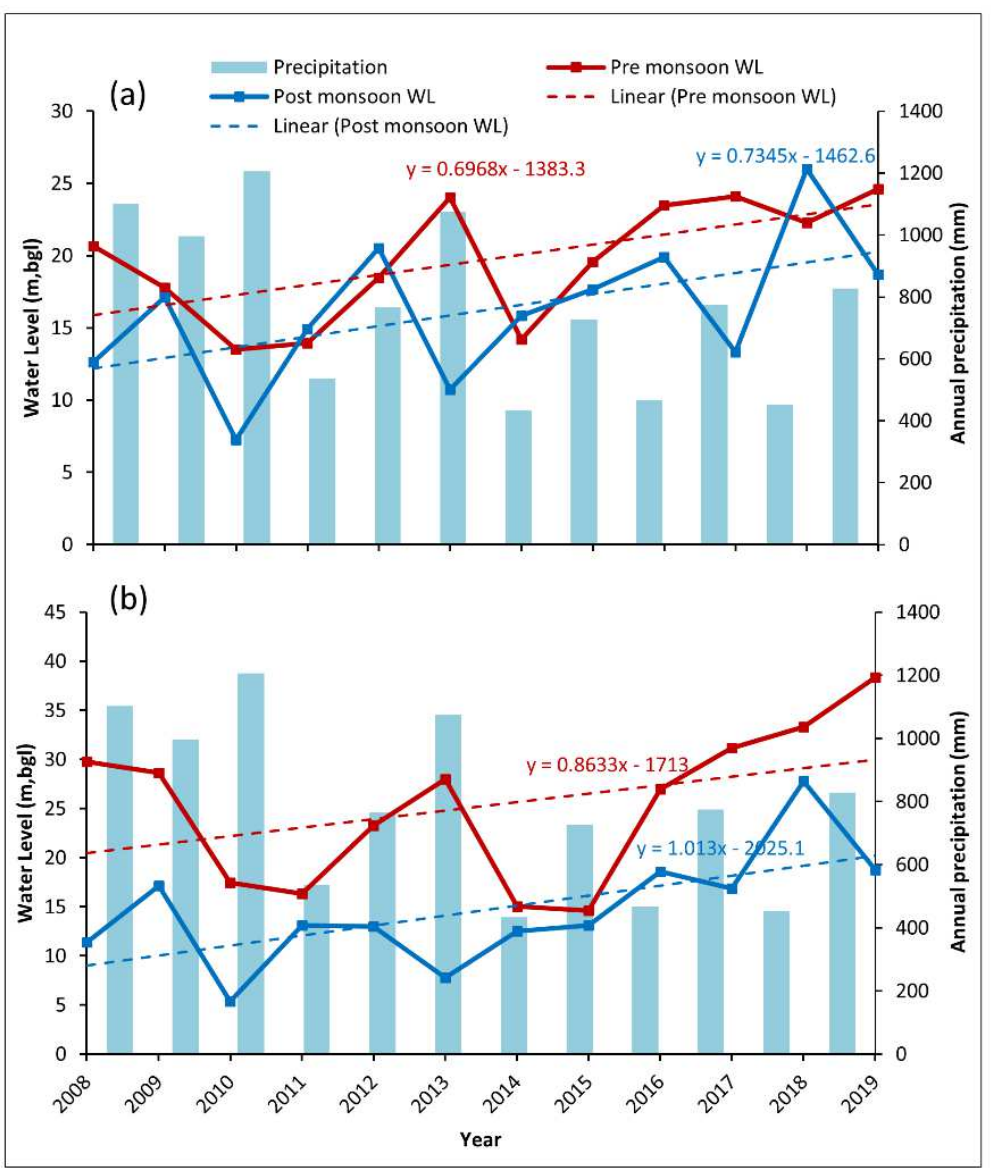

Figure. 6. Graph showing the temporal variation of water level fluctuation in the areas of (a) low recharge zone and (b) high recharge zone.

Groundwater management for agriculture sustainability. The estimated recharge rates vary widely within land use land cover settings. It has been noted that most of the paddy and forested areas with some orchards, vegetables and double crops are under the moderate potential recharge zones whereas some paddy and vegetables and a small part of the forest is coming under good recharge zones for the year 2008, 2014 and 2019. While mixed plantation along with some paddy and orchards have been practicing in the poor recharge zone. The 
differences in land use land cover, thus contribute to the wide contrast in recharging

417 processes. The relationship between land use land cover settings and groundwater recharge apparent in the current study allows for a better evaluation of the effect of future land-use changes on groundwater quantity.

420

\begin{tabular}{|c|c|c|c|c|}
\hline \multirow{2}{*}{$\begin{array}{l}\text { Recharge } \\
\text { zones }\end{array}$} & \multicolumn{3}{|c|}{ Year } & \multirow{2}{*}{$\begin{array}{l}\text { Average recharge } \\
\mathrm{mcm}\end{array}$} \\
\hline & 2008 & 2014 & 2019 & \\
\hline $\begin{array}{l}\text { Good } \\
(1.75 \mathrm{Sq} \\
\mathrm{km})\end{array}$ & $\begin{array}{l}\text { Some paddy, } \\
\text { double crops }\end{array}$ & Paddy, vegetables & $\begin{array}{l}\text { Small part of forest, } \\
\text { vegetables }\end{array}$ & 0.216 \\
\hline $\begin{array}{l}\text { Moderate } \\
\text { (32.93 sq. } \\
\mathrm{Km})\end{array}$ & $\begin{array}{l}\text { Some paddy, } \\
\text { orchards, } \\
\text { vegetables, } \\
\text { double crops, } \\
\text { forest }\end{array}$ & $\begin{array}{l}\text { Mostly paddy, forest, } \\
\text { vegetables }\end{array}$ & $\begin{array}{l}\text { Forest, vegetables, } \\
\text { paddy, orchards, other } \\
\text { crops }\end{array}$ & 3.882 \\
\hline $\begin{array}{l}\text { Poor }(17.71 \\
\text { sq. } \mathrm{Km})\end{array}$ & $\begin{array}{l}\text { Paddy, orchards, } \\
\text { vegetable, mixed } \\
\text { plantation, build- } \\
\text { up, barren, some } \\
\text { area of forest }\end{array}$ & $\begin{array}{l}\text { Some paddy and forest, } \\
\text { build-up }\end{array}$ & $\begin{array}{c}\text { Some forest, mostly } \\
\text { barren, some paddy and } \\
\text { orchards and other crops, } \\
\text { build-up }\end{array}$ & 1.619 \\
\hline $\begin{array}{l}\text { very Poor } \\
(0.06 \text { sq. } \\
\mathrm{Km})\end{array}$ & Barren, build-up & Build-up & Mostly barren & 0.002 \\
\hline
\end{tabular}

421

422

423

424

425

426

427

Table 2. Land use land cover in different potential recharge zones

Groundwater draft and recharge. The total estimated dynamic renewable groundwater recharge of the study area varies widely with an average of $5.7 \mathrm{mcm}$ from the last twelve years, while groundwater draft is $21.9 \mathrm{mcm}$ and hence the net deficit is $16.2 \mathrm{mcm}$ (Table 3 ).

Table 2 indicates there is an increase in groundwater draft from the year 2008 to 2019. On average, 13.1 percent of precipitation reaches into the groundwater by direct rainfall infiltration and by different systems of water storage for example tanks, reservoirs, etc. The percentage of rainfall that participated in the recharge has been significantly improved throughout the years. The total draft indicates the use of massive groundwater for irrigation. Temporal groundwater deficit has been varied throughout the years, these variations were due 
434 use and domestic uses, etc.

\begin{tabular}{ccccccc}
\hline Year & $\begin{array}{c}\text { Average } \\
\text { annual } \\
\text { rainfall } \\
(\mathrm{mm})\end{array}$ & $\begin{array}{c}\text { Rainfall } \\
(\mathrm{mcm})\end{array}$ & $\begin{array}{c}\text { Total water } \\
\text { use }(\mathrm{mcm})\end{array}$ & $\begin{array}{c}\text { Recharge } \\
(\mathrm{mcm})\end{array}$ & $\begin{array}{c}\text { Deficit } \\
(\mathrm{mcm})\end{array}$ & $\begin{array}{c}\text { Percentage of } \\
\text { rainfall } \\
\text { participated in } \\
\text { recharge (mcm) }\end{array}$ \\
\hline 2008 & 1102 & 58.2 & 21.3 & 7.9 & 13.4 & 13.6 \\
2009 & 997 & 52.7 & 21.3 & 6.9 & 14.4 & 13.1 \\
2010 & 1206 & 63.7 & 21.3 & 8.3 & 13.0 & 13.1 \\
2011 & 535 & 28.3 & 21.3 & 2.1 & 19.3 & 7.3 \\
2012 & 765 & 40.4 & 21.3 & 3.5 & 17.9 & 8.5 \\
2013 & 1074 & 56.7 & 21.3 & 11.1 & 10.3 & 19.5 \\
2014 & 434 & 22.9 & 22.5 & 1.1 & 21.4 & 4.9 \\
2015 & 726 & 38.3 & 22.5 & 1.8 & 20.7 & 4.6 \\
2016 & 467 & 24.7 & 22.5 & 4.9 & 17.6 & 19.8 \\
2017 & 774 & 40.9 & 22.5 & 8.5 & 14.0 & 20.7 \\
2018 & 452 & 23.9 & 22.5 & 1.9 & 20.6 & 8.1 \\
2019 & 828 & 43.7 & 22.6 & 10.7 & 11.9 & 24.5 \\
\hline Average & 780 & 41.2 & 21.9 & 5.7 & 16.2 & 13.1 \\
\hline
\end{tabular}

mcm: million cubic meters

436 Table 3. Groundwater recharge and use in the study area

437

438 With the present study, it is concluded that the GIS-based methods of delineating 439 groundwater recharge zones adopted here are a valuable tool that can be used for the 440 watershed-based planning and development of subtropical and tropical areas with the 441 different geo-environmental setting. This study also explained that local or site-specific soil 442 infiltration information may enhance the potential recharge zone mapping that would in turn 443 help better planning and management of groundwater resources.

445 Conclusion

446 The present research is an attempt to determine the classification of groundwater recharge

447 potentials by Weighted Overly Analysis using GIS methods in a semi-arid watershed located 448 in Telangana state, South India. The potential recharge zones have been categorized into four 
distinct groundwater recharge zones that are good, moderate, poor and very poor. The result shows that good potential recharge areas are mainly found in the valley and low drainage density areas, covering a very small area of about $3.3 \%$ considering soil infiltration rates and basement depths along with other thematic layers. The moderate groundwater recharge zones spread all over the catchment area in both the recharge maps, mainly in the shallow weathered pediplains of biotite granite and biotite granite with pegmatite and dyke and low lineament density. Poor and very poor groundwater recharge zones occur predominantly in uplands to lowlands but very poor recharge zones are relatively lesser in the midlands. The poor and very poor groundwater recharge zones found in the rocky outcrop, high drainage density, steep slope, less lineament density and less or no fissures and barren land regions and cover an area of about $41.4 \%$ and $2.2 \%$ respectively for the first map. The recharge potential map with infiltration rates and basement depth indicates an impressive change in poor and very poor zones with an increase in groundwater recharge potential. The demarcated potential recharge zone has a good correlation with pre and post-monsoon water level fluctuations. Estimation of groundwater recharge and draft shows there has been a substantial increase in the groundwater use as well as an impressive increase of rainfall participated in recharge in the last twelve years.

The groundwater recharge map of this study provides useful information for the decision on effective agricultural planning and groundwater management. Because most of the research area is dominated by crop and agricultural land, this work would help to improve and enhance the irrigation facilities and increase the region's agricultural productivity. The relationship between the settings of land use cover and groundwater recharge that is evident in the current study allows for a clearer assessment of the impact of potential changes in land

472 use on the quantity of groundwater. However, as the study shows a marked decline in 473 precipitation and hence water levels, it is necessary to consider and understand climatic 
inconstancy over the long term to properly plan and management of groundwater resources

475 well into the future. The major limitation of the study is the water budget that has been estimated with limited aquifer parameters and distributed rainfall that may influence the total

477 budget and its distribution. The water budget needs to be compared with groundwater 478 modeling results.

479 To meet the UN Sustainable Development Goals, it is imperative to quantify the in and out 480 fluxes to the system and based on their balance, further demand and budgeting be planned. 481 However, it is comparatively easy to estimate the out fluxes but very cumbersome to 482 precisely estimate the influxes. This study contributes significantly towards this but still a few 483 steps towards the final goal.

\section{Contributions:}

485 Data collection: Fauzia and AR; Data curation, interpretation and GIS modelling: Fauzia; 486 Conceptualization: Fauzia, SL and SA; Manuscript draft: Fauzia and SL; Improvements: SA 487 Acknowledgments:

488 The authors are highly thankful to the director CSIR-National Geophysical Research Institute 489 for providing all facilities for this research work and for giving permission to publish this 490 article (Ref. No. NGRI/Lib/2020/Pub-203). The first author has contributed this research 491 work under her Junior Research Fellow program funded by DST-INSPIRE, New Delhi, India 492 (IF180301). This research work is a part of her Ph.D. thesis. 


\section{References}

1. Magesh, N.S., Chandrasekar, N., and Soundranayagam, J.P. Delineation of groundwater potential zones in Theni district, Tamil Nadu, using remote sensing, GIS and MIF techniques. Geosci Front. 3, 189-196 (2012).

2. Shekhar, S. and Pandey, A.C. Delineation of groundwater potential zone in hard rock terrain of India using remote sensing, geographical information system (GIS) and analytic hierarchy process (AHP) techniques. Geocarto International. 30, (4) 402-421 (2015).

3. Schmidt, G., Subah, A., and Khalif, N. Climatic changes and water resources in the Middle East and North Africa. Environmental Science and Engineering, 23, 2941-2963 (2008).

4. Chenini, I., Mammou, A.B., and El May, M. Groundwater recharge zone mapping using GISbased multi-criteria analysis: a case study in Central Tunisia (Maknassy Basin). Water Resour. Manag. 24, (5) 921-939 (2010).

5. Mohanty, S., et al. Comparative evaluation of numerical model and artificial neural network for simulating groundwater flow in Kathajodi-Surua Inter-basin of Odisha, India. J Hydrol. 495, 38-51 (2013).

6. Surinaidu, L., Bacon, C.G.D., Pavelic, P. Agricultural groundwater management in the Upper Bhima Basin, India: current status and future scenarios. Hydrol. Earth Syst. Sci.17 (2), 507$517(2013)$.

7. Souissi, D., Msaddek, M.H., Zouhri, L., Chenini, I., El May, M., \& Dlala, M. Mapping groundwater recharge potential zones in arid region using GIS and Landsat approaches, southeast Tunisia. Hydrolog Sci J. 63 (2), 251-268 (2018).

8. Gleenson, T., et al. Illuminating water cycle modifications and earth system resilence in the Anthropocene. Water Reseourc. Res. 56. E 24390 (2020).

9. Surinaidu, L., et al. Reviving the Ganges Water Machine: Accelerating surface water and groundwater interactions in the Ramganga Sub-basin. J Hydrol. 540, 207-219 (2016). 
10. Rahman, A., Tiwari. K.K., Mondal, N.C. Hydrochemical characterization for groundwater suitability in a semi-arid area in Sanganer Block, Jaipur District, Rajasthan, India. J Geol Soc India. 96, 399-409 (2020).

11. Freeze, R.A., Cherry, J.A. Groundwater. Prentice-Hall, New Jersey (1979).

12. Chowdhury, A., Jha, M.K., Chowdary, V.M., Mal, B.C. Integrated remote sensing and GISbased approach for assessing groundwater potential in West Medinipur. https://www.tandfonline.com/doi/full/10.1080/01431160802270131 (2009).

13. Jhariya, D.C., et al. Assessment of groundwater potential zone using remote sensing, GIS and multicriteria decision analysis techniques. J. Geol. Soc. India 88 (4), 481-492 (2016).

14. Lentswe, G,B., Molwalefhe, L. Delineation of potential groundwater recharge zones using analytic hierarchy process-guided GIS in the semi-arid Motloutse watershed, eastern Botswana. J. Hydrol: Regional Studies. 28, 100674 (2020).

15. Beekman, H.E., Xu, Y. Review of groundwater recharge estimation in arid and semi-arid southern Africa. Groundwater Recharge Estimation in Southern Africa (2003).

16. Scanclon, B.R., Keese, E.K., Flint, A.L., Flint, L.E. Global synthesis of groundwater recharge in semiarid and arid regions. Hydrol. Process. 20, 3335-3370 (2006).

17. Scanlon, B.R., Healy, R.W., Cook, P.G. Choosing appropriate techniques for quantifying groundwater recharge. Hydrogeol. J. 10,18-39 (2002).

18. Lerner, D.N., Thornton, S.F., Davison, R.M. The use of monitored natural attenuation as a costeffective technique for groundwater restoration. Groundwater (2000).

19. Sophocleous, M. Groundwater recharge. Groundwater in Encyclopedia of Life Support Systems (EOLSS), Development Under the Auspices of the UNESCO. Eolss Publishers, Oxford (2004).

20. Carver, S.J. Integrating multi-criteria evaluation with geographical information systems. Int. J. Geogr. Inf. Syst. 5 (3), 321-339 (1991).

21. Malczewski, J. GIS and Multicriteria Decision Analysis. John Wiley and Sons, New York (1999). 
22. Machiwal, D., Jha, M.K., Mal, B.C. Assessment of groundwater potential in a semi-arid region of India using remote sensing, GIS and MCDM techniques. Water Resour. Manag. 25, $1359-1386(2011)$

23. Kaliraj, S., Chandrasekar, N., Magesh, N.S. Identification of potential groundwater recharge zones in Vaigai upper basin, Tamil Nadu, using GIS-based analytical hierarchical process (AHP) technique. Arab. J. Geosci. 7 (4), 1385-1401 (2014).

24. Pinto, D., Shrestha, S., Babel, M.S., Ninsawat, S. Delineation of groundwater potential zones in the Comoro watershed, Timor Leste using GIS, remote sensing and analytic hierarchy process (AHP) technique. Appl. Water Sci. 7, 503 (2017).

25. Yeh, H.F., Cheng, Y.S., Lin, H.I., Lee, C.H. Mapping groundwater recharge potential zone using a GIS approach in Hualian River, Taiwan. Sustain. Environ. Resour. 26, 33-43 (2016).

26. Raviraj, A., Kuruppath, N., Kannan, B. Identification of potential groundwater recharge zones using remote sensing and geographical information system in Amaravathy Basin. J. Remote. Sens. GIS 6, 4 (2017).

27. Saha, S. Groundwater potential mapping using analytical hierarchical process: a study on Md. BazarBlock of Birbhum District, West Bengal. Spat. Inf. Res. 25, 615-626 (2017).

28. Arulbalaji, P., Padmalal, D., Sreelash, K. GIS and AHP techniques based delineation of groundwater potential zones: a case study from southern western ghats, India. Sci. Rep. 9, $2082(2019)$.

29. Chenini, I., Mammou, A. B. Groundwater recharge study in arid region: An approach using GIS techniques and numerical modeling. Comput and Geosci. 36 (6), 801-817 (2010).

30. Hachem, A.M.Y., Ali, E., Abdelhadi, El O., Abdellah, El H., Said, K. Using remote sensing and GIS-multicriteria decision analysis for Groundwater potential mapping in the middle atlas plateaus, Morocco. Res. J. Recent Sci. 4 (7), 33-41 (2015).

31. Al-Adamat, R. The use of GIS and Google Earth for Preliminary Site Selection of Groundwater Recharge in the Azraq oasis area-Jordan. JWARP. 4 (6), 395-399 (2012). 
32. Al-Shabeeb, A.R. A Modified analytical hierarchy process method to select sites for groundwater recharge in Jordan. Leicester. s.n. (2015).

33. Houston, J.F.T., Lewis, R.T. The Victoria Province drought relief project, II. Borehole yield relationships. Ground Water 26 (4), 418-426 (1988).

34. Davis, S.N., Turk, L.J. Optimum depth of wells in crystalline rocks. Ground Water. 2 (2), 6-11 (1964).

35. Wyns, R., et al. Application of SNMR soundings for groundwater reserves mapping in weathered basement rocks, Brittany, France. Bull Soc Géol France 175, 21-34 (2004).

36. Sreedevi, P.D., Ahmed, S., Made, B., Ledoux, E., Gandolfi, J. M. Association of hydrogeological factors in temporal variations of fluoride concentration in a crystalline aquifer in India. Environ Geol. 50, 1-11 (2006)

37. Dewandel, B., Lachassagne, P., Wyns, R., Maréchal, J. C., and Krishnamurthy, N. S. A generalized 3D geological and hydrogeological conceptual model of granite aquifers controlled by single or multiphase weathering. J Hydrol. 330, 260-284 (2006).

38. Maréchal JC, Galeazzi L, Dewandel B, Ahmed S. Importance of irrigation return flow on the groundwater budget of a rural basin in India. IAHS Pub. 278, IAHS, Wallingford, UK. $62-$ 67 (2003).

39. Khan, H.H., Khan, A., Ahmed, S., Perrin, J. GIS-based impact assessment of land-use changes on groundwater quality: study from a rapidly urbanizing region of South India. Environ Earth Sci. 63,1289-1302 (2011).

40. Mare'chal, J.C., Dewandel, B., Subrahmanyam, K. Contribution of hydraulic tests at different scales to characterize fracture network properties in the weathered-fissured layer of a hard rock aquifers. Water Resour. Res. 40, W11508 (2004).

41. DIN 19682-7. Soil quality - Field studies - Part 7: Determination of the infiltration rate with the double cylinder infiltrometer. https://www.beuth.de/de/norm/din-19682-7/98059952 (1997).

42. De Condappa, D., Galle, S., Dewandel, B., Haverkamp, R. Bimodal zone of the soil textural triangle: common in tropical and subtropical regions. Soil Phys. 72 (1) (2006). 
44. Rashid, M., Lone, M, A., and Ahmed, S. Integrating geospatial and ground geophysical information as guidelines for groundwater potential zones in hard rock terrains of south India. Environ Monit Assess. 184, 4829-4839 (2012).

45. Kumar, P. K., Gopinath, G., Seralathan, P. Application of remote sensing and GIS for the demarcation of groundwater potential zones of a river basin in Kerala, southwest coast of India. Int. J. Remote Sens. 28, 5583-5601 (2007).

46. ESRI. ArcGIS Desktop: Release 10.3. Environmental systems research, Redlands, CA (2015).

47. Saaty, T.L. A scaling method for priorities in hierarchical structures. J. Math. Psychol. 15, 231281 (1977).

48. Brunnelli, M. Introduction to the analytic hierarchy process. Springer, Amsterdam (2015).

49. NRSA. Integrated mission for sustainable development -technical guidelines, National Remote Sensing Agency, Dept. of Space, Hyderabad (1995).

50. NRSA. Technical guidelines for preparation of groundwater prospects map. Rajiv Gandhi National Drinking Water Mission, National Remote Sensing Agency, Hyderabad (2000).

51. Ground Water Estimation Committee (GEC). Rep. of ground water resource estimation methodology. Ministry of Water Resource, Government of India, New Delhi. 105 (1997).

52. Varalakshmi, V., Rao B. V., Surinaidu L., and Tejaswini M. Groundwater flow modeling of a hard rock aquifer: case study. J. Hydrol. Eng. 19, 5 (2014).

53. Stako, S., Tarka, R., and Olichwer, T. Groundwater recharge evaluation based on the infiltration method. doi: 10.1201/b12715-19 (2012).

54. Kumar, M. G., Agarwal, A. K., \& Bali, R. Delineation of potential sites for water harvesting structures using remote sensing and GIS. J. Indian Soc. Remote. Sens. 36, 323-334 (2008).

55. Anbazhagan, S., Ramasamy, S. M., Das Gupta, S. Remote sensing and GIS for artificial recharge study, runoff estimation and planning in Ayyar basin, Tamil Nadu, India. Environ Geol. 48, 158-170 (2005).

56. Rahman, A., Tiwari. K.K., Mondal, N.C. Assessment of hydrochemical backgrounds and threshold values of groundwater in a part of desert area, Rajasthan, India. Environ. Pollut. 266, 115150 (2020). 

Tata McGraw Hill (1999). approach using remote sensing, using remote sensing, GIS and resistivity techniques: a case study from a hard rock terrain. Int. J. Remote Sens. 27 (20), 4599-4620 (2006). 


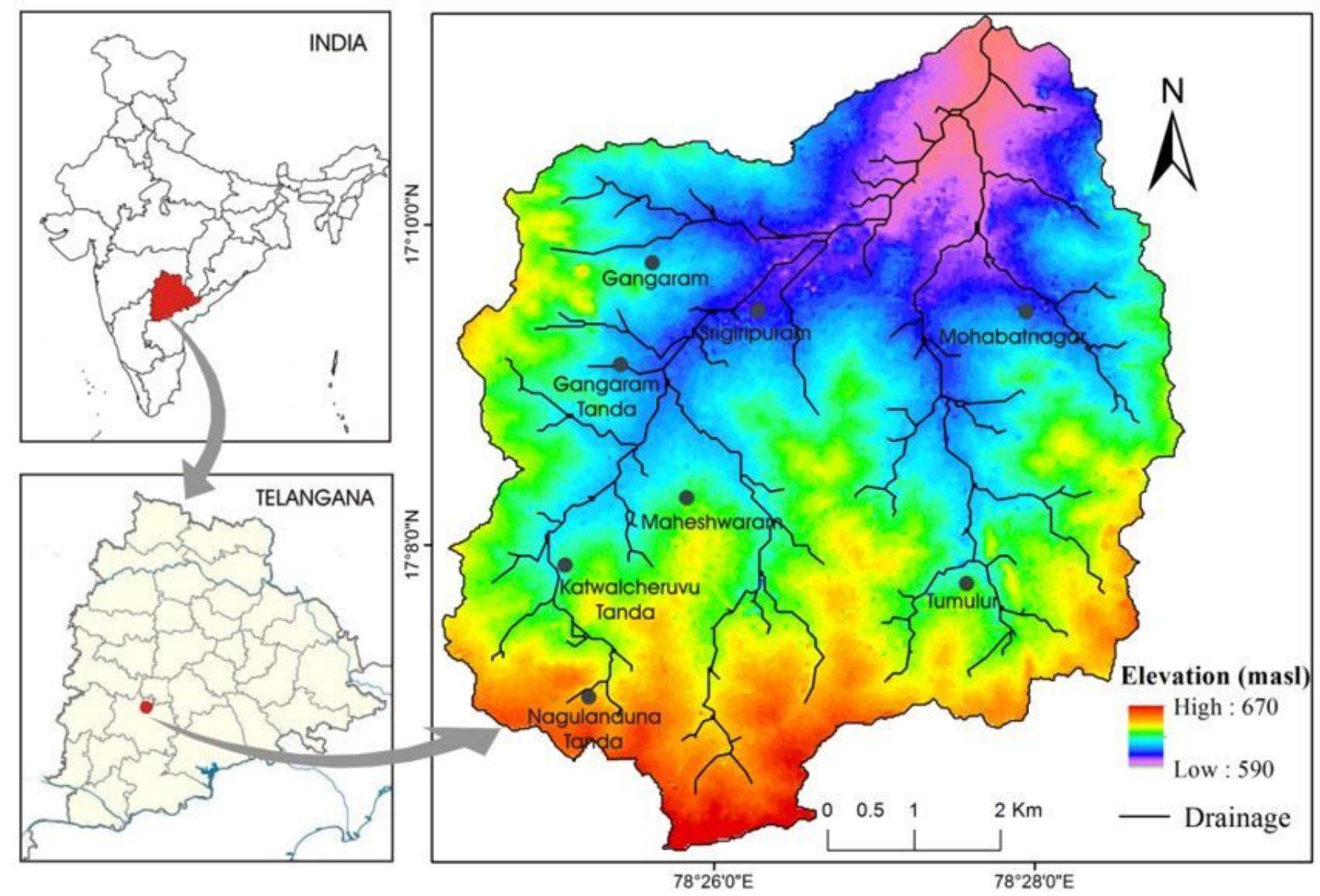

Figure 1

Location map of the study area showing elevation with the drainage system Note: The designations employed and the presentation of the material on this map do not imply the expression of any opinion whatsoever on the part of Research Square concerning the legal status of any country, territory, city or area or of its authorities, or concerning the delimitation of its frontiers or boundaries. This map has been provided by the authors. 


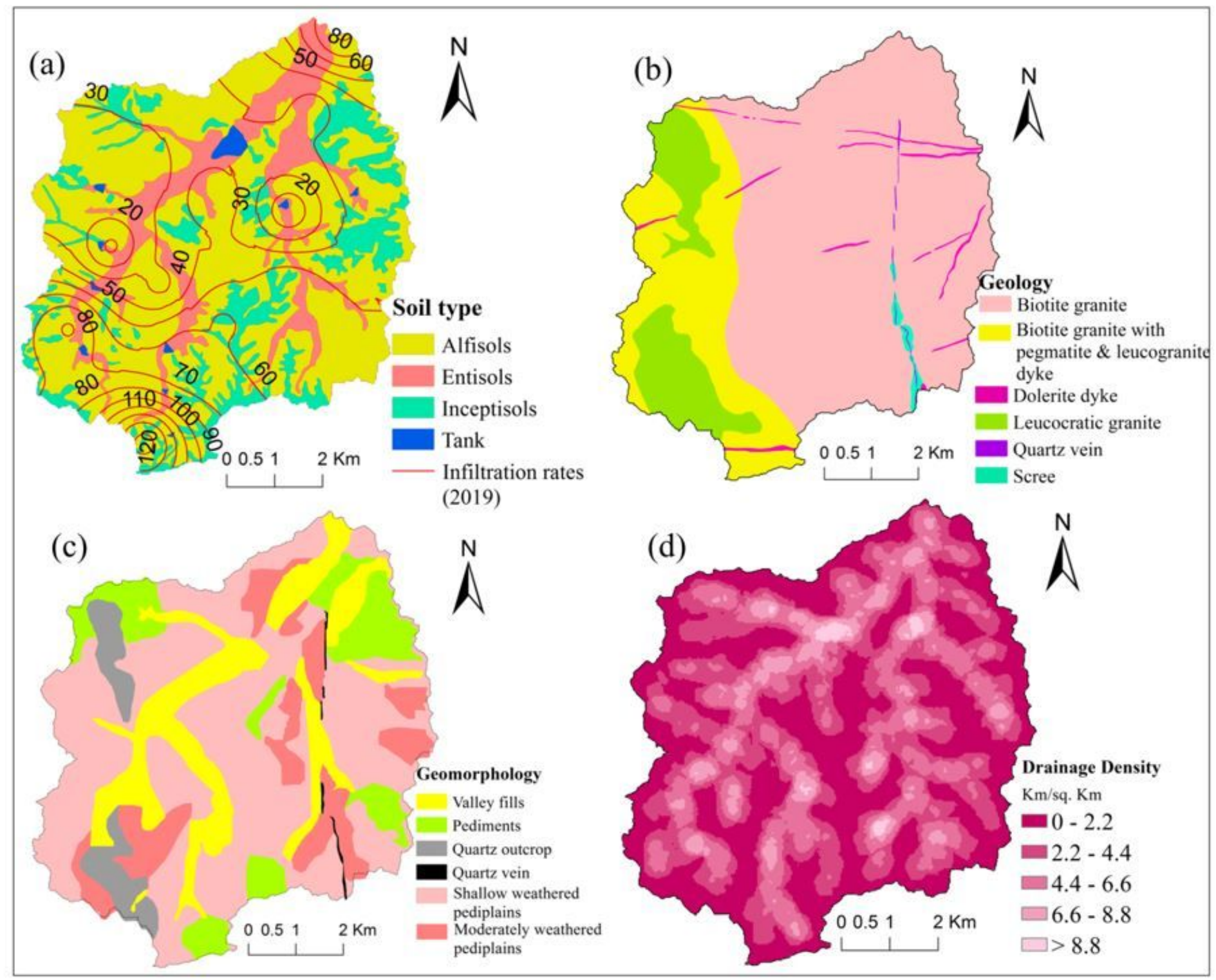

Figure 2

Map showing input thematic layers (a) soil with infiltration rates ( $\mathrm{mm} / \mathrm{hr}),(\mathrm{b})$ geology, (c) geomorphology, and (d) drainage density of Maheshwaram watershed, India. 2.3.5. Slope Note: The designations employed and the presentation of the material on this map do not imply the expression of any opinion whatsoever on the part of Research Square concerning the legal status of any country, territory, city or area or of its authorities, or concerning the delimitation of its frontiers or boundaries. This map has been provided by the authors. 

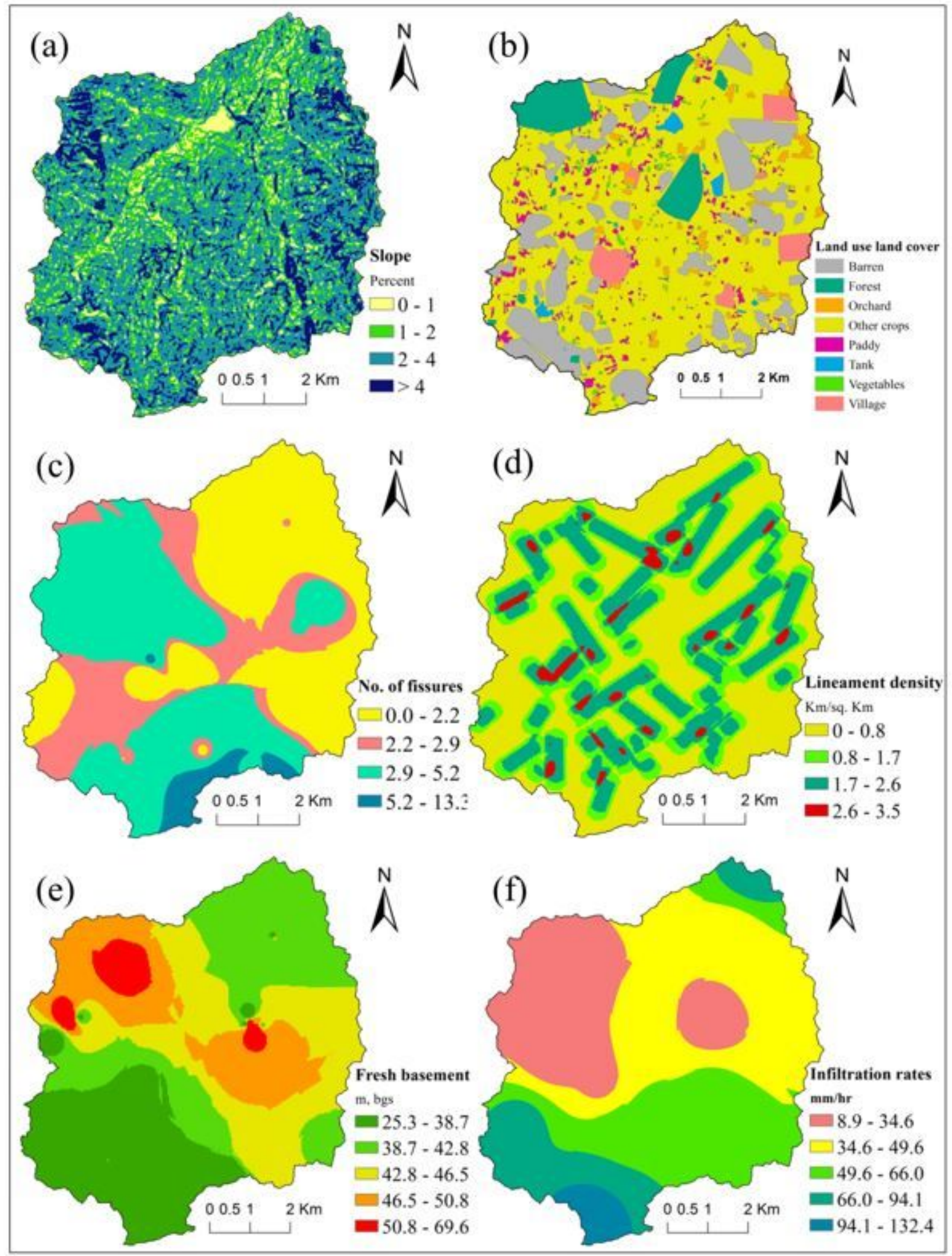

\section{Figure 3}

Map showing input thematic layers (a) slope (b) Lulc (c) fissures (d) lineament density, (e) depth to basement, and (f) infiltration rates of Maheshwaram watershed, India. Note: The designations employed and the presentation of the material on this map do not imply the expression of any opinion whatsoever on the part of Research Square concerning the legal status of any country, territory, city or area or of its 
authorities, or concerning the delimitation of its frontiers or boundaries. This map has been provided by the authors.

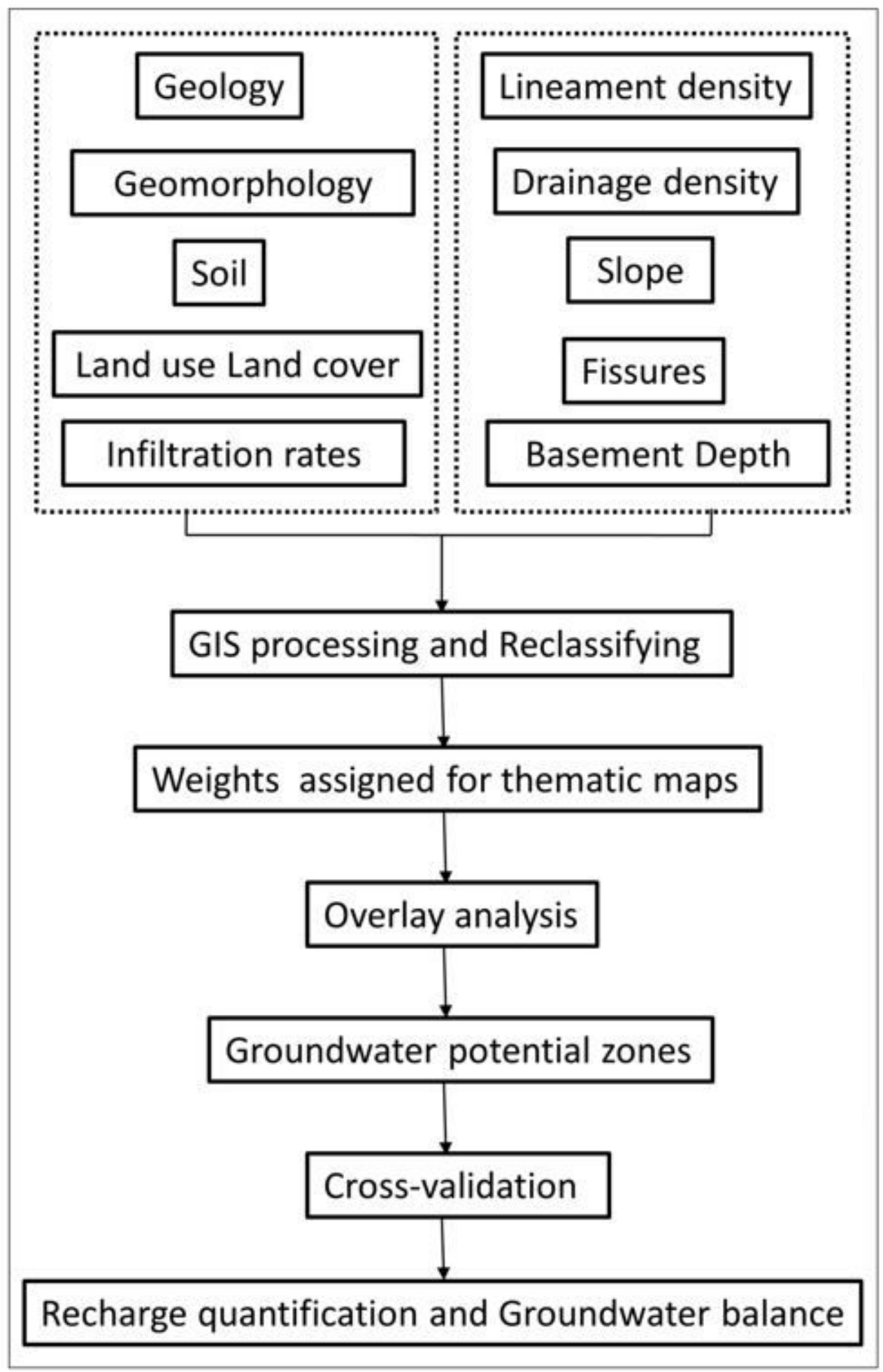

Figure 4

Flow chart showing WOI methodology adopted in the study area for the evaluation of potential groundwater recharge zones. 


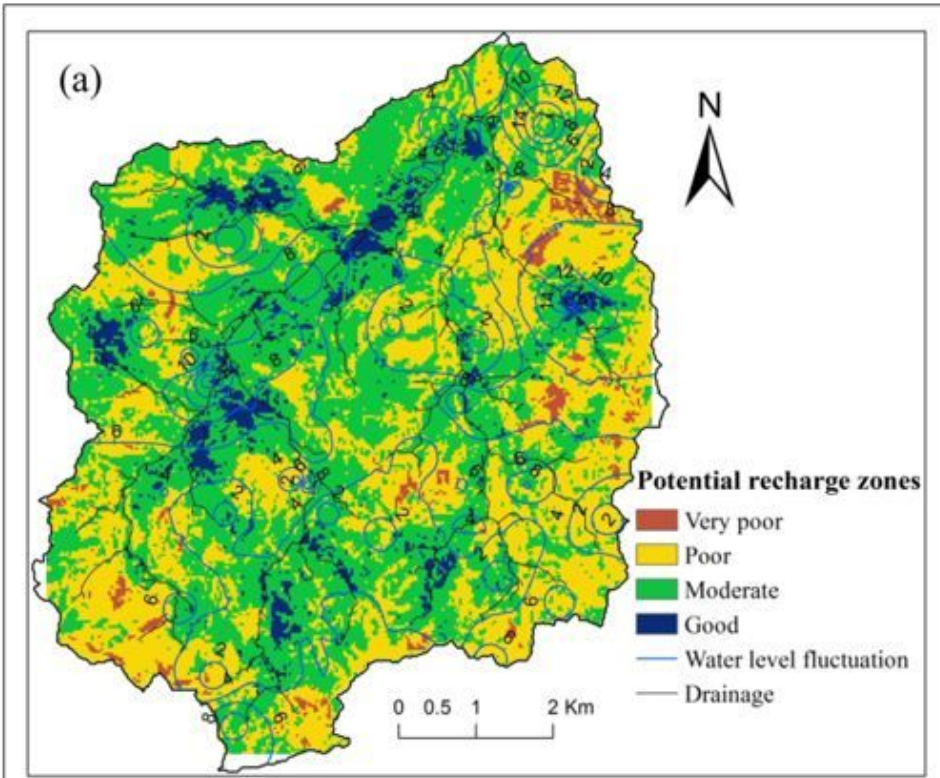

Area in percentage

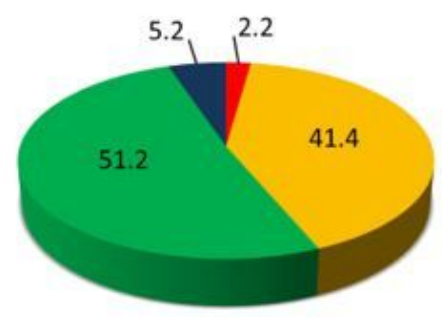

- Very poor

= Poor

Moderate

a good

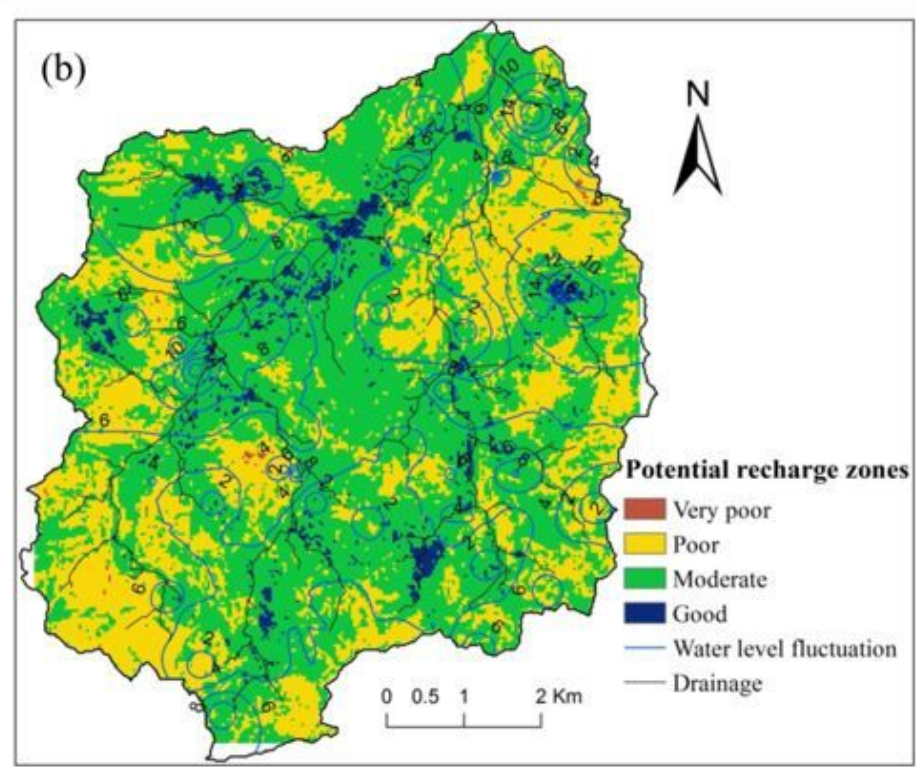

Area in percentage

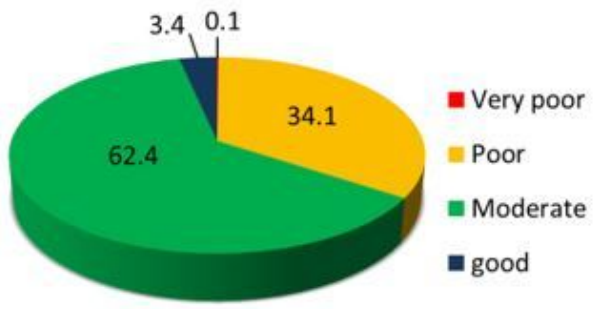

\section{Figure 5}

Potential groundwater recharge zones (a) without infiltration rates and basement depth (b) with infiltration rates and basement depth. Note: The designations employed and the presentation of the material on this map do not imply the expression of any opinion whatsoever on the part of Research Square concerning the legal status of any country, territory, city or area or of its authorities, or concerning the delimitation of its frontiers or boundaries. This map has been provided by the authors. 


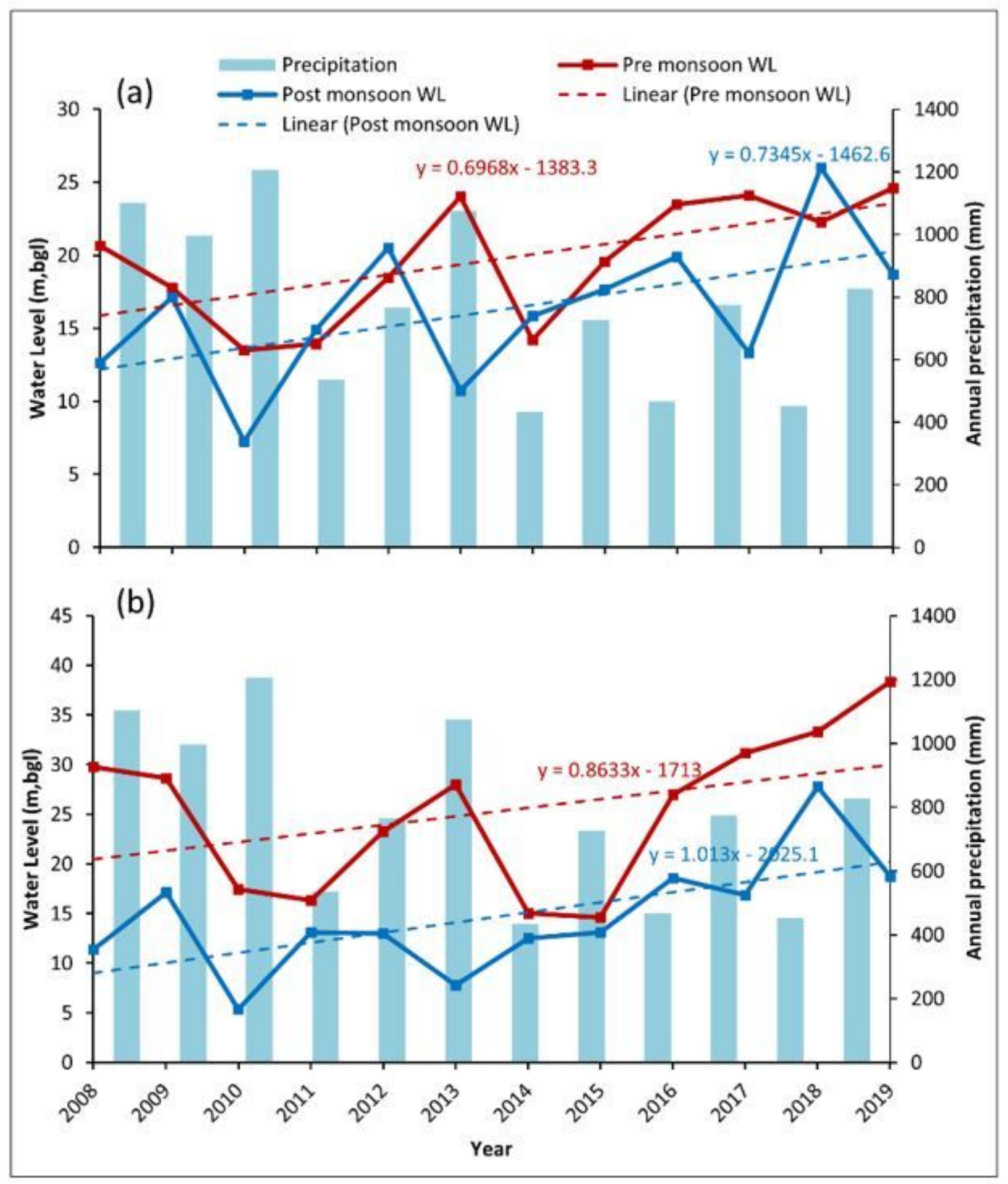

\section{Figure 6}

Graph showing the temporal variation of water level fluctuation in the areas of (a) low recharge zone and (b) high recharge zone. 